OPEN ACCESS

Edited by:

Thanos Dailianis,

Hellenic Centre for Marine Research,

Greece

Reviewed by:

Anna Occhipinti-Ambrogi,

University of Pavia, Italy

Daniel Rittschof,

Duke University, United States

*Correspondence:

Grant Hopkins

grant.hopkins@cawthron.org.nz

${ }^{\dagger}$ These authors have contributed

equally to this work

Specialty section:

This article was submitted to

Marine Biology,

a section of the journal

Frontiers in Marine Science

Received: 16 August 2021 Accepted: 24 September 2021 Published: 12 October 2021

Citation:

Hopkins G, Davidson I,

Georgiades E, Floerl O, Morrisey D and Cahill P (2021) Managing

Biofouling on Submerged Static

Artificial Structures in the Marine

Environment - Assessment of Current

and Emerging Approaches.

Front. Mar. Sci. 8:759194.

doi: 10.3389/fmars.2021.759194

\section{Managing Biofouling on Submerged Static Artificial Structures in the Marine Environment - Assessment of Current and Emerging Approaches}

\author{
Grant Hopkins $^{1 * t}$, Ian Davidson ${ }^{1 \dagger}$, Eugene Georgiades ${ }^{2 t}$, Oliver Floerl'1, Donald Morrisey ${ }^{1}$ \\ and Patrick Cahillit
}

${ }^{1}$ Cawthron Institute, Nelson, New Zealand, ${ }^{2}$ Biosecurity New Zealand, Wellington, New Zealand

The number, extent, diversity, and global reach of submerged static artificial structures (SSAS) in the marine environment is increasing. These structures are prone to the accumulation of biofouling that can result in unwanted impacts, both immediate and long-term. Therefore, management of biofouling on SSAS has a range of potential benefits that can improve structure functions, cost-efficiency, sustainability, productivity, and biosecurity. This review and synthesis collates the range of methods and tools that exist or are emerging for managing SSAS biofouling for a variety of sectors, highlighting key criteria and knowledge gaps that affect development, and uptake to improve operational and environmental outcomes. The most common methods to manage biofouling on SSAS are mechanical and are applied reactively to manage biofouling assemblages after they have developed to substantial levels. Effective application of reactive methods is logistically challenging, occurs after impacts have accumulated, can pose health and safety risks, and is costly at large scales. Emerging technologies aim to shift this paradigm to a more proactive and preventive management approach, but uncertainty remains regarding their long-term efficacy, feasibility, and environmental effects at operational scales. Key priorities to promote more widespread biofouling management of SSAS include rigorous and transparent independent testing of emerging treatment systems, with more holistic cost-benefit analyses where efficacy is demonstrated.

Keywords: antifouling, aquaculture, biocorrosion, biosecurity, energy, marinas, ports, coastal infrastructure

\section{INTRODUCTION}

A burgeoning human population is dramatically increasing the number, extent, diversity, and reach of submerged static artificial structures (SSAS) in the marine environment (Firth et al., 2016; Todd et al., 2019; Floerl et al., in press). Over the last century, floating pontoons, industrial water-use structures (e.g., power plants), oil and gas rigs, desalination plants, marine-farming installations, wave buoys, turbines, and other renewable-energy infrastructure have added to increasing amounts of traditional structures (Bugnot et al., 2020; Floerl et al., in press). All of these structures are subject to constant colonization pressure by microorganisms, macroalgae, and invertebrates - commonly 
referred to as biofouling (Wahl, 1989) - with wide-ranging consequences for SSAS functions and the environment.

Although the adverse effects of biofouling on ships have been well known and subject to management activities since ancient times (e.g., Phoenicians 1300 BCE, Woods Hole Oceanographic Institute [WHOI], 1952), recognition of biofouling impacts on SSAS are relatively recent. For example, engineers in the Netherlands in the 1730s were caught unawares by disastrous effects of shipworm (Teredo navalis) on wooden revetments of the country's seawalls (Sundberg, 2015), even though ships had been actively managing against these effects for centuries (Woods Hole Oceanographic Institute [WHOI] 1952). Contemporary parallels are occurring in Venice as biofouling accumulations hamper the installation and functioning of its novel flood barrier system (MOSE; see Giovannini, 2017). Sea-water intakes and associated internal pipework of coastal factories, desalination plants, and power stations also have a well-documented history of problems from biofouling, particularly bivalves (Satpathy et al., 2010; Polman et al., 2013). In aquaculture operations, biofouling can result in biocorrosion (Li and Ning, 2019; Omran and AbdelSalam, 2020), increased weight loading and hydrodynamic drag (Macleod et al., 2016; Vinagre et al., 2020), and production losses (e.g., occlusion, disease, competition, escape, or stock drop off) (Georgiades et al., 2016; Bannister et al., 2019). In nuclear power plants, biofouling has caused significant pressure drops in cooling water systems that impose serious production penalties and can instigate safety concerns (Neitzel et al., 1984, Satpathy, 1999). All of these direct outcomes necessitate heightened engineering considerations prior to installation to cope with loss of hydrodynamic performance, weight loading scenarios, and impaired functioning that requires increased initial investment, operating, and maintenance costs (Jenner et al., 1998; Polman et al., 2013).

The environmental effects of SSAS and ecological role of their biofouling communities are becoming increasingly important as hardened coastlines (e.g., seawalls and revetments) and other types of artificial structures proliferate worldwide. SSAS biofouling affects functioning of nearshore marine ecosystems including population and community distribution processes (Chapman, 2003; Bulleri and Chapman, 2010), and biogeochemical processing (Malerba et al., 2019). SSAS (particularly in ports and harbors) are often the first point of establishment for marine non-indigenous species (NIS) (Floerl et al., 2009; Bell et al., 2011; Woods et al., 2019) and associated pathogens (e.g., Bonamia ostreae, Howard, 1994; Ostreid herpesvirus, Whittington et al., 2018; PagenkoppLohan et al., 2020), and subsequently act as 'reservoirs' that facilitate spread to the surrounding natural environment (Glasby et al., 2007). The down-stream implications of NIS and pathogens can be catastrophic and irreversible, impacting other industries, the environment, and cultural practices (International Maritime Organization [IMO], 2004, 2011; Molnar et al., 2008; Mineur et al., 2012; Georgiades et al., 2021). As a result, vector management requirements for ballast water have been established worldwide (International Maritime Organization [IMO], 2004), several jurisdictions have enacted stricter border standards regarding vessel biofouling
(Ministry for Primary Industries, 2014; California Code of Regulations, 2017), and domestic vessel movements among regions are increasingly scrutinized and managed (Cunningham et al., 2019). Despite these enacted and emerging vector controls, biofouling of static infrastructure remains an important node of species populations that requires further research to understand and mitigate risk. For example, to support the early detection and response to NIS incursions, surveillance programs have been developed to determine the presence and distribution of NIS in urbanized environments, with emphasis on submerged coastal infrastructure (e.g., Seaward et al., 2015; Woods et al., 2019; McDonald et al., 2020).

Minimizing biofouling on maritime vessels remains a focus of significant global research and development - forming the basis of a multi-billion dollar "antifouling coating" industry because of impacts on speed, manoeuvrability, operability, and durability (Woods Hole Oceanographic Institute [WHOI], 1952; Yebra et al., 2004; Callow and Callow, 2011). More recently, vessel biofouling management has been further incentivized by guidelines and regulations regarding NIS translocations (Davidson et al., 2016; Georgiades et al., 2020a). By comparison, managing biofouling on SSAS has received limited attention, with a status quo of resigned acceptance of impacts and consequences. This dichotomy reflects clear economic incentives, which are well-documented for maritime vessels where even 'light' biofouling causes hydrodynamic penalties that can dramatically increase power requirements, fuel usage, and associated emissions (Townsin, 2003, International Maritime Organization [IMO], 2011; Schultz et al., 2011). The benefits of preventing biofouling on SSAS are less apparent or longer term, but there is a growing awareness that unmanaged fouling on these structures can also threaten economic, environmental, and socio-cultural values (e.g., Polman et al., 2013; Atalah et al., 2020). Proactive biofouling management of these structures is often context specific or experimental, but there is an emerging array of approaches and tools that could offer viable solutions for broad applicability, scalability, and cost-effectiveness.

The objectives of this assessment are to highlight the current impacts of biofouling on SSAS and to review current and emerging approaches to biofouling management on these structures. In the context of this article, "management" is restricted to approaches for preventing, removing and/or rendering biofouling on SSAS non-viable. While ecological engineering approaches can also be used to limit the abundance of unwanted or harmful biofouling organisms (e.g., NIS) by enhancing the development of desirable species on SSAS this was not included in our review, whose emphasis is on prevention or minimization of all biofouling. Ecological engineering is a growing field in marine science and conservation and opportunities, frameworks, and methods have been reviewed and presented elsewhere (Dafforn et al., 2015; Airoldi et al., 2021; Floerl et al., in press).

Firstly, an overview of motivations for biofouling management is provided for various categories of SSAS, along with existing biofouling management approaches. Then, emerging approaches are identified, including some that are untested at operational scales or yet to be applied to SSAS (e.g., 
vessel biofouling management approaches that may solve SSAS issues). For each existing and emerging approach identified, prospective performance characteristics are qualitatively evaluated against criteria of feasibility, effectiveness, biosecurity, and collateral effects. These criteria can inform a set of research and development priorities to guide technological development and enable industries, governments, and other agencies to minimize the consequence of SSAS biofouling.

\section{EXISTING APPROACHES TO BIOFOULING MANAGEMENT ON STATIC INFRASTRUCTURE}

Three categories of SSAS were the primary focus of this review: aquaculture, energy production, and port and marina infrastructure (see Figure $\mathbf{1}$ for example images). There are SSAS that fall outside of these categories (e.g., recreational jetties, bridges, outfalls, dykes, and some groins and breakwaters) and some of them have relevance with regard to biofouling and the spread of NIS (Airoldi et al., 2015). However, in most cases they are either treated using the same approaches identified for the three categories assessed or not presently managed for biofouling within their service life.

Two approaches were taken to build a reference library of accounts of SSAS biofouling and its management. Firstly, a standardized literature search was performed using Web of Science, Google Scholar, and Google Search. Keywords selected were "marine infrastructure," "pontoon," "wharf," "pile," "piling," “jetty," “sea wall," “seawall," "break wall," "breakwall," "rig," "installation," "marine farm," "aquaculture," and "turbine” associated with any of the following (with fouling or biofouling as a prefix): "management," "maintenance," "inspection," "cleaning," "defouling," "removal," and "control." Secondly, unpublished documents and information from websites were obtained from various companies (globally) who either manage or own infrastructure (e.g., marina companies), or undertake maintenance on coastal infrastructure (e.g., commercial divers).

\section{Aquaculture}

The intensity of biofouling management on marine farms varies by the species cultured and environmental conditions, and can include management of infrastructure (e.g., anchor warps, lines, nets, and cages) and the stock itself (e.g., bivalves). The key motivations for biofouling management on finfish farms include reduced water flows and dissolved oxygen levels via net pen occlusion, increased disease risk due to increased stress and direct interactions with biofouling communities, and impairment of infrastructure due to loading and impingement (Fitridge et al., 2012; Bannister et al., 2019). Direct operational impacts are the primary driver of management to reduce the likelihood of these types of impacts. Bloecher and Floerl (2020) calculated direct biofouling management costs for a typical Norwegian salmon farm (eight production pens) to be US\$420,000 to $\$ 493,600$ per production cycle (excluding farm personnel costs), equating to $2.2 \%$ of production costs for individual sites. Biofouling species common to aquaculture structures can act as reservoirs and

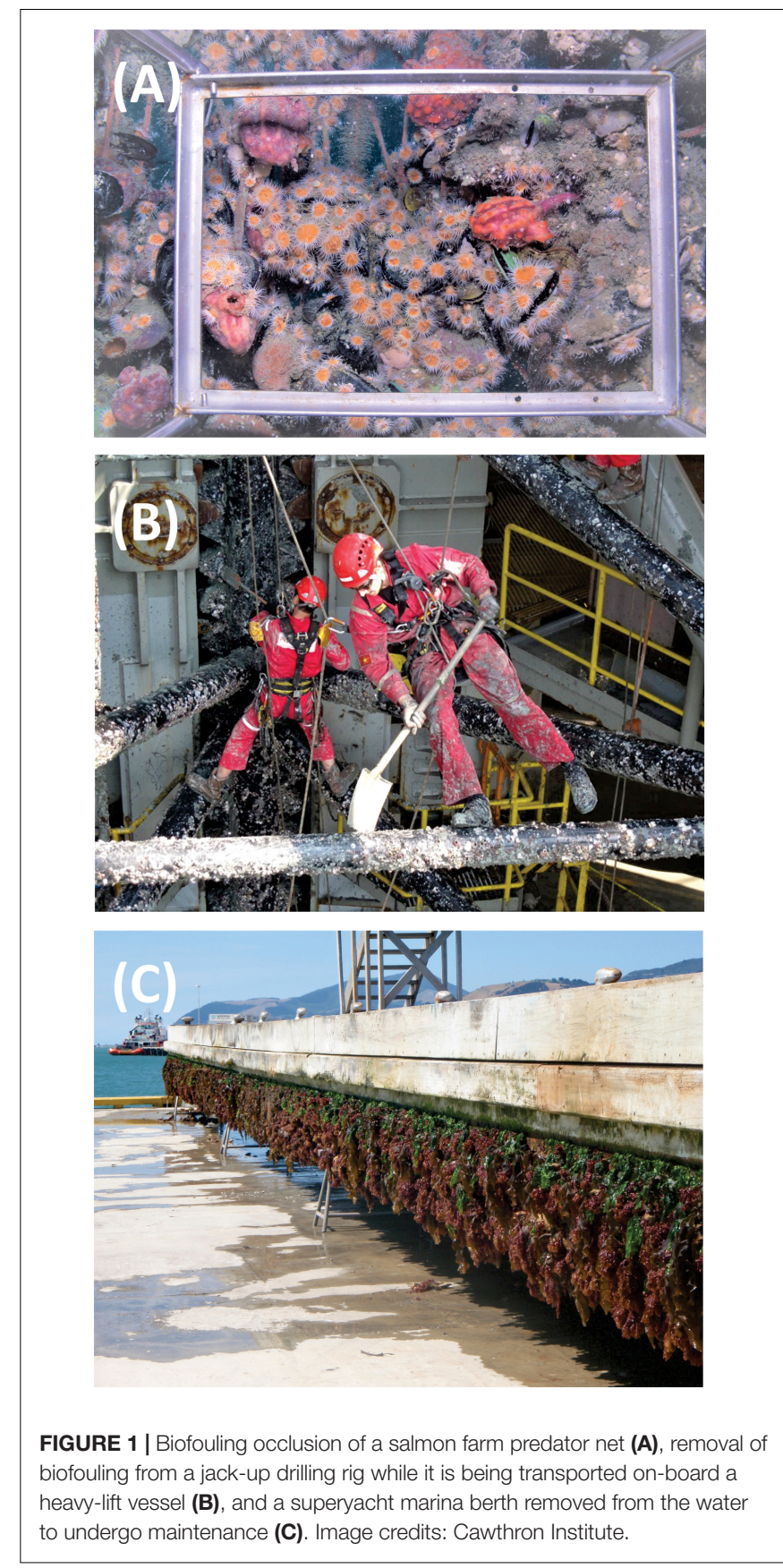

amplifiers of pathogens (Costello et al., 2021), which can impact stock or broader disease dynamics within a seascape. There is growing recognition of the role of aquaculture in spreading marine pests and pathogens (Sim-Smith et al., 2016), and industry codes of practice and government guidance documents have been developed to improve outcomes in New Zealand and elsewhere (Georgiades et al., 2016, 2020a,b; Ministry for Primary Industries and Aquaculture New Zealand, 2016).

Biofouling on shellfish farms can result in physical damage to stock, mechanical interference with harvesting gear, competition for food and space, environmental modification, and 
TABLE 1 | Existing approaches to managing biofouling on static submerged marine infrastructure.

\begin{tabular}{|c|c|c|c|c|}
\hline Method & Category & Frequency & $\begin{array}{l}\text { In situ or } \\
\text { Removed }\end{array}$ & Examples/References \\
\hline $\begin{array}{l}\text { Mechanical } \\
\text { brushes/scraping/abrasion }\end{array}$ & Physical & Periodic & Both & $\begin{array}{l}\text { Do (1991); Hodson et al. (1997), Guenther et al. (2011), and Li } \\
\text { et al. (2020) }\end{array}$ \\
\hline $\begin{array}{l}\text { High pressure jets and } \\
\text { power washing }\end{array}$ & Physical & Periodic & Both & Forrest and Blakemore (2006) and Hopkins et al. (2010) \\
\hline Air exposure/desiccation & Physical & Periodic & Both & Forrest and Blakemore (2006) and Hopkins et al. (2016) \\
\hline $\begin{array}{l}\text { Encapsulation (also with } \\
\text { chemical additives) }\end{array}$ & $\begin{array}{l}\text { Physical and } \\
\text { chemical }\end{array}$ & Periodic & In situ & Inglis et al. (2012); Atalah et al. (2016), and Ammon et al. (2019) \\
\hline Traditional biocidal paints & Chemical & Continuous & Removed (majority) & $\begin{array}{l}\text { Braithwaite et al. (2007); de Nys and Guenther (2009), Guenther } \\
\text { et al. (2011), and Bloecher et al. (2015) }\end{array}$ \\
\hline Sprays and dips & Chemical & Periodic & Both & $\begin{array}{l}\text { Denny (2008); Guenther et al. (2011), Fitridge et al. (2012), and } \\
\text { Sievers et al. (2019) }\end{array}$ \\
\hline
\end{tabular}

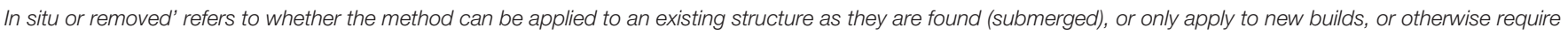
removal from water.

hydrodynamic drag and weight on both stock and infrastructure (Dürr and Watson, 2010; Fitridge et al., 2012; Georgiades et al., 2016; Bannister et al., 2019). Adams et al. (2011) found that management costs for biofouling on US shellfish farms approximates $15 \%$ of total operating costs (excluding any loss in productivity). As with finfish farming, disease outbreaks are a major disruptor for shellfish farm operations and non-stock biofouling can exacerbate those risks while also occupying space that would otherwise be profitably taken by stock species.

A broad range of approaches has been used to manage biofouling growth on marine farm stock and infrastructure (Table 1), including the use of biocidal paints (de Nys and Guenther, 2009; Bannister et al., 2019), high pressure jets/power washing (Forrest and Blakemore, 2006), chemical sprays and dips (Denny, 2008; Guenther et al., 2011; Fitridge et al., 2012), encapsulation (Atalah et al., 2016), and removal for cleaning (e.g., cleaning of finfish farm predator nets). Physical and mechanical removal of biofouling are the main management approaches for shellfish aquaculture, while finfish operations tend to use antifouling coatings (e.g., copper-based paints), undertake regular net changes and/or cleaning and, in rarer cases, use biological control (Fitridge et al., 2012; Georgiades et al., 2016; Bloecher and Floerl, 2020).

Most measures employed are reactive (i.e., address biofouling after it has established), inefficient, can have undesirable consequences (e.g., chemical contamination and pathogen transfer, Sandberg and Olafsen, 2006; Erkinharju et al., 2020), and can be too costly to apply at an appropriate frequency (Cahill et al., 2021). There is a trend for aquaculture activities to move away from coastal zones into more open seas, partly to reduce adverse effects on the environment (Carballeira Braña et al., 2021). This is likely to make it more difficult to remove stock and infrastructure from the water for biofouling management and, consequently, encourages more proactive or continuous approaches. One such approach is the development of a system to "flip" oyster baskets (at the surface) periodically to desiccate biofouling ${ }^{1}$ (accessed June 25, 2020).

${ }^{1}$ https://www.flipfarm.co.nz

\section{Energy Production}

Accumulation of biofouling on energy production infrastructure can increase drag (Macleod et al., 2016; Vinagre et al., 2020), affect cathodic protection (leading to corrosion), create microenvironments that encourage microbial corrosion (Blackwood et al., 2017; Li and Ning, 2019), reduce water flow in cooling systems (Venkatesan and Murthy, 2009), compromise health and safety of operators (e.g., sharp or slippery fouling on stairs and ladders), and endanger the entire plant (Satpathy and Rajmohan, 2001). Considerable costs are associated with over-engineering to combat hydrodynamic impacts and weight loadings during SSAS development as well as the requirements for extensive inspection and ongoing post-deployment maintenance (Klijnstra et al., 2017; Loxton et al., 2017).

Several approaches have been developed for preventive or reactive treatment of biofouling within land-based industrial water-cooling systems (e.g., power plants and water treatment plants) that use bulk seawater (Rajagopal and Van der Velde, 2012). Treatments based on chlorine and heat exposure are the most common due to their versatility and cost effectiveness (Jenner et al., 1998; Venkatesan and Murthy, 2009; Satpathy et al., 2010; Costa et al., 2012).

For the offshore energy sector, the impacts of biofouling on submerged infrastructure also include harboring and spreading NIS (Yeo et al., 2010; De Mesel et al., 2015; Capel et al., 2019; Iacarella et al., 2019; Coolen et al., 2020). Many offshore structures, such as drilling rigs and oil platforms, remain static for extended periods during operations and layups, typically leading to extensive biofouling growth (Hopkins and Forrest, 2010; Georgiades and Kluza, 2017; Gormley et al., 2018). This can represent a major invasion risk that can involve translocations of entire communities, including biofouling or reef-forming species and associated mobile fauna (Foster and Willan, 1979; Wanless et al., 2010; Yeo et al., 2010). When biofouling becomes extensive, or when structures require mitigation prior to deployment to meet biosecurity requirements (e.g., Ministry for Primary Industries 2014), there are limited or challenging options available for removal and/or treatment (Hopkins and Forrest, 2010; Iacarella et al., 2019). A key difference between drilling 
rigs and other energy infrastructure, such as wind farms and wave turbines, is that some rigs can be relocated to maintenance facilities or to other sites of operation. Biofouling removal can occur while a rig remains in-water or while on-board a heavy-lift vessel (Hopkins and Forrest, 2010; Hopkins et al., 2011).

Removal of established biofouling assemblages often requires long-term planning due to the limited facilities that can accommodate energy production structures. This "reactive" practice is typically mechanical (e.g., hydro-blasting, cavitation, diver-, and remotely operated vehicle (ROV)-operated brushes) and must be re-applied frequently, often leading to high overall cost and feasibility issues. Because antifouling coatings are designed almost exclusively for use on ship hulls and require water flow to remain effective (Dafforn et al., 2011; Larsson et al., 2016; Xie et al., 2019), they are rarely applied in energy production. Instead, coatings seen on energy production structures are designed to limit or manage corrosion (e.g., epoxypolyurethane duplex coating systems or metal sprayed coatings; Versowsky, 2005; Sørensen et al., 2009; Eom et al., 2020) as stipulated by ISO standards (International Organization for Standardization [ISO], 2016). Biofouling on niche areas of rigs, such as sea chests and internal pipework, is generally managed similarly to vessels, e.g., regular inspections, chemical dosing, cathodic protection, physical removal, and the application of antifouling paints for sea chests (Davidson et al., 2016; Growcott et al., 2017; Georgiades et al., 2018). Omran and AbdelSalam (2020) proposed future avenues to combat biofouling in the oil and gas industry, including plant-based biocides (e.g., aqueous extracts of lupin seed and citrus peels) to treat micro- and macro-fouling, and polymer coatings to combat corrosion (e.g., polymers combined with biocides, antibacterial polymers containing quaternary ammonium compounds, and conductive polymers).

We are aware of one product, Marine Growth Protector Rings, that have been developed to continually clean surfaces on offshore installations (Do, 1991). These devices consist of buoyant rings, linked by vertical linkages, that are powered up and down column-shaped surfaces by waves and tides. While performance evaluations were unavailable, it is claimed that these devices can remove existing fouling (reactive) and prevent fouling from reoccurring (continuous).

The planned service life of an offshore wind structure typically exceeds 20 years; therefore, to avoid large-scale and costly repairs, they are designed to resist mechanical damage, physical and environmental loadings, and chemical deterioration (Price and Figueira, 2017). Intertidal and splash zones of an offshore wind structure are typically protected from corrosion by applying multi-layer epoxy-based coatings with a polyurethane topcoat prior to installation (Momber et al., 2015). Subtidal components typically use a combination of coatings and cathodic protection. Repairing coatings on offshore wind structures can be very difficult and expensive, costing up to 50 times more than the initial application (Price and Figueira, 2017). These issues could be overcome with more resilient or self-healing coatings (Cho et al., 2009; Stankiewicz et al., 2013; Zhang et al., 2018).

Wave-power generation (e.g., through wave energy convertors) is not a widely employed commercial technology compared to other established renewable energy sources, but there are now installations off the coasts of the United Kingdom, Portugal, Australia, Sweden, and the United States. Simulations by Yang et al. (2017) showed that biofouling on mooring lines and power cables associated with wave energy converters reduced energy performance (up to $17 \%$ ) and caused significant reductions (up to $76 \%$ ) in the fatigue life of moorings. Wave energy converters have been designed for 20-25 years of maintenance-free service, however, supporting infrastructure such as safety lines, underwater cables, and subtidal equipment may be prone to biofouling (Rémouit et al., 2018). As an emerging technology, there is little information on biofouling management approaches for wave energy converters, although manual or mechanical cleaning via diving and ROVs may be required (Rémouit et al., 2018) and should be considered in economic forecasting.

\section{Port and Marina Infrastructure}

Port and marina environments contain vast arrays of SSAS, including breakwalls, pontoons, wharves and jetties, seawalls, navigational markers, and launching ramps. These structures are typically made of concrete, steel, plastic and wood, and serve a variety of functions to harden shorelines, protect maritime access and infrastructure, or support on-water activities. A recent assessment found that shipping and boating related SSAS occupied on average $20 \%$ of coastlines associated with 30 coastal urban centers around the world, with marina pontoons making up the highest proportion, followed by commercial wharves and jetties (Floerl et al., in press).

The need for proactive biofouling management in port and marina environments varies substantially among the types of structures. For example, loose rock or concrete breakwalls that protect coastal transit routes are not managed for biofouling accumulation. Biofouling is rarely managed unless it affects the operation of floating jetties or pontoons. For most marina structures, biofouling growth is either not managed during the service life of submerged structures, periodically removed by scraping (by surface personnel), or they are opportunistically cleaned (often by water blasters) when removed to land for other maintenance needs. In some cases, coatings, preservative treatments (treated wood), or 'sleeving' is employed as a proactive treatment of materials to prevent or reduce deterioration (including deterioration caused by biofouling and bioeroders). Damage from ship worms (T. navalis) and wood boring isopods (e.g., Sphaeroma spp.) to timber structures (e.g., wharf piles) can lead to complete failure of structures (Tsinker, 2004), meaning chemical treatments (e.g., linseed oil, biocides, and creosote) or physical barriers (e.g., plastic or copper sheathing) are deployed. However, no treatment method has been found to be completely effective to date (Sundberg, 2015).

In commercial ports, concrete or wood pilings can number in the thousands and are continually monitored by port dive teams as part of annual inspection schedules, which often includes removal of biofouling to assess structural integrity of materials (Tsinker, 2004). In this case, biofouling is removed in patches as it hinders inspection, although the broader impacts of biofouling for increased weight, drag forces, and acceleration of 
TABLE 2 | Emerging approaches to managing biofouling on submerged marine infrastructure.

\begin{tabular}{|c|c|c|c|c|}
\hline Method & Category & Frequency & $\begin{array}{l}\text { In situ or } \\
\text { Removed }\end{array}$ & Examples/References \\
\hline $\begin{array}{l}\text { Autonomous and remotely } \\
\text { operated cleaning systems }\end{array}$ & Physical & Both & In situ & $\begin{array}{l}\text { https://www.jotun.com/us/en/b2b/news/hull-skating-solutions/; } \\
\text { https://www.ecosubsea.com/(September 12, 2020) }\end{array}$ \\
\hline Laser radiation & Physical & Periodic & In situ & Kostenko et al. (2019) \\
\hline Bubble streams & Physical & Continuous & In situ & $\begin{array}{l}\text { Scardino et al. (2009); Bullard et al. (2010), Lowen et al. (2016), and } \\
\text { Hopkins et al. (2021) }\end{array}$ \\
\hline Ultrasound & Physical & Periodic & In situ & Guo et al. (2013, 2011) and Legg et al. (2015) \\
\hline Electrical fields & Physical & Continuous & In situ & www.electroclear.co.nz (accessed May 13, 2020) \\
\hline Heat & Physical & Periodic & Both & $\begin{array}{l}\text { Wotton et al. (2004); Piola and Hopkins (2012), Cahill et al. (2019b), and } \\
\text { Sievers et al. (2019) }\end{array}$ \\
\hline $\begin{array}{l}\text { Novel coatings and surface } \\
\text { materials }\end{array}$ & $\begin{array}{l}\text { Physical and } \\
\text { chemical }\end{array}$ & Continuous & Removed (majority) & $\begin{array}{l}\text { Hodson et al. (2000; silicone), Scardino et al. (2003), de Nys and Ison } \\
\text { (2004; wax), Carman et al. (2006); Schumacher et al. (2007), Bakker } \\
\text { et al. (2011; food grade oils), Carteau et al. (2014); Azemar et al. (2015), } \\
\text { Gibson and Arun (2016); Yang et al. (2018), and Ye et al. (2019) }\end{array}$ \\
\hline Biological control & Biological & Continuous & In situ & $\begin{array}{l}\text { Enright et al. (1984); Lodeiros and García (2004), Ross et al. (2004); } \\
\text { Switzer et al. (2011), and Atalah et al. (2014) }\end{array}$ \\
\hline
\end{tabular}

corrosion are also acknowledged in port construction (Tsinker, 2004). Navigational buoys are periodically maintained (e.g., physical scraping and water blasters) to prevent sinking due to excess loading (Mitchem et al., 2007). Permanent systems to proactively manage biofouling are largely absent for the majority of infrastructure found in ports and marinas. A lack of biofouling removal or prevention can be compounded by the semi-enclosed nature of these environments leading to vastly increased rates of biofouling development in ports and marinas compared to adjacent areas (Floerl and Inglis, 2003).

Wrapping or encapsulation in plastic or fabric has been used to eliminate NIS on SSAS associated with ports and marinas, and on vessels (Anderson, 2005; Coutts and Forrest, 2007; Roche et al., 2015). To date, this approach has primarily been adopted to remove particular NIS as part of eradication or incursion response efforts rather than a biofouling removal technique, even though the effect is typically all encompassing (i.e., wrapping affects all target and non-target taxa). There can be questionable efficacy without the addition of chemical treatment within the wrap and some maintenance and monitoring of encapsulations (Inglis et al., 2012). The potential loss of plastic to the environment is also a drawback, as is the amount of waste generated over time (in most cases, wraps are not reusable). Encapsulation materials are likely to become fouled over time unless they have antifouling properties, and there is some time sensitivity to the approach to ensure they do not become heavily fouled themselves, potentially exacerbating the problem. The development of improved encapsulation fabrics to assist with ease and speed of deployment would be beneficial, especially if they can be reused and reapplied without significant cost or environmental risk (e.g., detachment of NIS, see Coutts et al., 2010).

\section{EMERGING BIOFOULING MANAGEMENT APPROACHES}

Our review of the literature identified a range of existing and emerging approaches to prevent and manage biofouling on static infrastructure, including approaches initially developed for vessels that could be refined for SSAS (Table 2).

\section{Physical/Mechanical Methods}

Remotely operated marine robotics have been developed to remove biofilms and macrofouling from vessel hulls ${ }^{2,3}$ (accessed September 12, 2020). Similarly, Kostenko et al. (2019) reported on the use of ROVs to inspect and clean vessel submerged surfaces using laser radiation. Remotely operated brush systems are used to remove fouling from finfish farm production nets (e.g., Bloecher and Floerl, 2020). It is reasonable to expect that systems could be developed to continuously inspect and clean other categories of SSAS. However, there are challenges to overcome, such as heterogeneous surfaces, the sometimes disconnected nature of SSAS, and power supply for devices.

Continuous bubble streams, or micro-bubbles, have shown promise in preventing biofouling accumulation on vessels (Scardino et al., 2009) and submerged marina materials (Bullard et al., 2010). More recently, Hopkins et al. (2021) undertook laboratory and field trials to determine the efficacy of continuous bubble streams over surfaces, focusing on materials typically used to construct marina pontoons (concrete and polyethylene) and with and without foul- release coatings typically used on vessels. No macroscopic fouling developed on treated panels after exposure in the marine environment for 4 months. By contrast, untreated control panels were completely covered by mature fouling assemblages. While there are several barriers to upscaling this approach, including the initial cost of installation, power consumption, and ongoing maintenance (e.g., keeping bubble diffusers fouling-free), the approach is promising as a potential 'set-and-forget' proactive antifouling solution for static structures (Hopkins et al., 2021).

Legg et al. (2015) reviewed acoustic methods for biofouling management and concluded that ultrasonic $(>20 \mathrm{kHz})$ frequencies were preferable to audio frequencies $(20 \mathrm{~Hz}$ to

\footnotetext{
${ }^{2}$ https://www.jotun.com/us/en/b2b/news/hull-skating-solutions

${ }^{3}$ https://www.ecosubsea.com/
} 
$20 \mathrm{kHz}$ ) due to potential environmental effects associated with underwater noise and the potential to increase biofouling settlement at certain frequencies on sound generating surfaces (see Wilkens et al., 2012; McDonald et al., 2014). Equipment used to generate ultrasonic frequencies typically include a signal generator/power amplifier and transducers, with antifouling effectiveness decreasing with distance from the transducer (Legg et al., 2015). Results indicate that lower ultrasonic frequencies may be suitable for treating vessel hulls, but optimal operating parameters must be refined to cater for a broad range of fouling organisms (Legg et al., 2015). Legg et al. (2015) also highlighted the need for greater rigor when testing efficacy to ensure proper replication, controls, quantitative response variables, and photographic documentation of responses. These considerations apply broadly, including for some emerging possibilities using electric fields to prevent biofouling accumulation ${ }^{4}$ (accessed April 12, 2021).

Heat has shown promise as an environmentally friendly tool to manage biofouling on exterior hulls (e.g., Hull Surface Treatment ${ }^{5}$ accessed August 2, 2021), internal pipework (Cahill et al., 2019b), and sea chests (Piola and Hopkins, 2012) of vessels. Use on SSAS has been limited but has included an eradication attempt of the Asian kelp Undaria pinnatifida found on a shipwreck (Wotton et al., 2004), and on natural shoreline habitats (Hunt et al., 2009). Sievers et al. (2019) tested combinations of treatment (heat and two acids) on two aquaculture species (a mussels and oyster) as well as three common biofouling pests (a hydroid and two ascidians). They observed varying levels of success with some of the pest species targeted, and for all but one species (the ascidian Styela clava), were able to attain effective treatments without adversely affecting the culture species.

\section{Biological Control}

Biological control to manage biofouling on marina pontoons, wharf piles, and aquaculture structures has shown promise (Enright et al., 1984; Lodeiros and García, 2004; Ross et al., 2004; Switzer et al., 2011). Atalah et al. (2014) found that two species of gastropod (Cookia sulcata and Haliotis iris) could largely prevent biofouling development over 3 months on pre-cleaned marina pontoons, including inhibiting colonization of several high-profile NIS. Cookia sulcata was also effective in reducing established fouling cover and biomass on wharf piles by $\approx 70 \%$ over a 3-month period. However, retention rates for C. sulcata, the most promising candidate on pontoons, was relatively low ( $<50 \%$ after 20 days and $<20 \%$ after 60 days) when not contained within a cage. Retention without additional infrastructure is likely needed for widespread adoption since fouling of the cage must also be considered.

Biological approaches to marine biofouling management have the potential to result in unanticipated impacts to the wider ecosystem (Atalah et al., 2013). The use of native natural enemies, termed augmentative biocontrol (Eilenberg et al., 2001), undoubtedly reduces this risk compared to classical

\footnotetext{
${ }^{4}$ https://www.auckland.ac.nz/en/news/2018/11/14/bioengineers- tackleunderwater-fouling-in-new-way.html

${ }^{5}$ https://commercialdiving.com.au/wp-content/uploads/HST-Research.pdf
}

biocontrol approaches (Atalah et al., 2014), but nonetheless the potential for non-target effects must be considered prior to implementation.

\section{Novel Coatings and Surface Materials}

Ideally, extensive global research to develop alternative coating technologies ( $\mathrm{Gu}$ et al., 2020; Yan et al., 2020) will provide non-polluting alternatives that reduce biofouling build up on SSAS. There has been a wealth of research into environmentally benign alternative antifouling biocides based on bioactive natural products. A wide range of antifouling bioactives have been discovered from marine and terrestrial invertebrates, plants, and microbes (Qian et al., 2015; Liu et al., 2020), with varied modes of action (Qian et al., 2013). The potency of some natural products compares favorably to available biocides and booster biocides, and in some instances synthetic or semi-synthetic derivatization has further improved potency relative to the parent molecule (e.g., Moodie et al., 2017; Wei et al., 2017; Almeida et al., 2018). However, natural products have not yet translated into useable antifouling products.

Common barriers from research and development to a marketable product (Ravel, 2020) include limitation of supply (i.e., many natural products are present in small quantities in nature and are difficult to access synthetically); inappropriate physico-chemical characteristics (i.e., incompatible with coating matrix systems or suboptimal stability); and regulatory challenges (i.e., data requirements and approvals to bring a new biocide to market). A related approach that has seen some success has been development or repurposing of synthetic bioactives. For example, medetomidine is a synthetic drug first developed as a surgical anesthetic and analgesic and is now used as a deterrent of barnacle settlement (Loxton et al., 2017). This bioactive has been successfully registered and marketed as Selektope ${ }^{\text {TM }}$ by ItechAB (Sweden) as the first novel antifouling biocide to enter the global market in recent times (Chaabane et al., 2019). Examples of other synthetic bioactives being pursued or developed include cationic short peptides that disrupt membrane integrity of biofoulers (Trepos et al., 2015) and anti-parasiticides (e.g., ivermectins) incorporated in soft coatings to 'contact kill' biofouling (Pinori, 2013).

Another rich area of research and development is novel nonbiocidal antifouling coatings and materials. A diverse range of approaches have been trialed and progressed to varying degrees for three main classes of coating/material: foul-release, surface topography, and physico-chemical. Novel foul-release coatings are diverse, with approaches ranging from high-tech amphiphilic polymer composites and fluropolymers (Selim et al., 2017; Rahimi et al., 2021) to comparatively low-tech coatings impregnated with silicone (Hodson et al., 2000), wax (de Nys and Ison, 2004), or food-grade oils (Bakker et al., 2011). Antifouling surfaces with engineered surface topographies mimic natural fouling resistant surfaces such as mussel shells and shark skin (Myan et al., 2013; Sullivan and O'Callaghan, 2020). Surface topography effects work by producing slightly smaller surface configurations than target biofouling larvae to prevent easy contact with the surface and hierarchical topography theoretically provides protection against a range of biofouling organisms 
(multi-scale roughness spanning micrometers to nanometers; Schumacher et al., 2007). Antifouling activity is influenced by texture design and the ratio between the height, width, or pitch of the surface features and settling organism length. The approach is intuitively attractive but has often failed to translate from laboratory to real-world (Carve et al., 2019). A possible reason for this is the lack of taxonomic diversity of biofouling organisms explored in laboratory studies, compared with highly unpredictable recruitment patterns found in nature encompassing a diversity of taxa with settlement preferences that span multiple orders of magnitude of topographical lengthscales.

Physico-chemical surface properties that deter or exclude fouling settlement are also widely studied. Examples include chemical modification of surface wettability (Li and Guo, 2019), photocatalytic surface chemistry (Zhang et al., 2019; Szeto et al., 2020), oil- or air-trapping polymers (Arnott et al., 2014; Ware et al., 2018), and sol-gels (Richards et al., 2019; Wanka et al., 2020). Many foul-release, surface topography, and physico-chemical approaches show promise, presenting potential avenues for truly environmentally benign and longlasting antifouling protection but product commercialization is low compared to research outputs (Sullivan and O'Callaghan, 2020). Common hurdles to be overcome include cost, scalability, and the requirement of specific physical environments (e.g., foul-release typically requires strong water flow sufficient to dislodge fouling). Combining multiple approaches (e.g., surface topography plus photocatalysis; Vucko et al., 2013) could overcome challenges presented by the range of biofouling attachment mechanisms and dynamic environment in the sea (Yan et al., 2020).

It is important to highlight that biocidal and non-biocidal coatings would need to last the lifetime of the structure or be refreshed or reapplied at appropriate frequencies to remain effective. This may be feasible for certain infrastructure such as aquaculture installations with growing cycles in the order of months to 1 or 2 years, but represents a formidable challenge for structures like wharf piles, marina pontoons, and renewable energy infrastructure where reapplication is not possible nor cost-effective under most scenarios. Other major challenges for emerging biocidal coatings for SSAS include registration procedures and regulatory requirements for new compounds and, for aquaculture, meeting strict food-safety requirements, and satisfying consumer perceptions. Ensuring that novel coatings and materials are environmentally acceptable is also a key barrier to implementation. Novel biocides are, by definition, intended to kill or otherwise exert control over organisms, resulting in overall high likelihoods for environmental harm (de Campos et al., 2021). Moreover, antifouling formulations typically contain multiple bioactive constituents that can have additive environmental risks to significantly complicate risk assessments, and this also applies for non-biocidal coatings that can contain an array of ingredients with bioactive potential (e.g., preservatives, catalysts, and fluorinated compounds; Piazza et al., 2018). Accordingly, regulatory data package requirements to bring any new antifouling active or formulation to market are extensive.

\section{FRAMEWORK FOR PERFORMANCE EVALUATION}

\section{Approach}

For there to be high levels of uptake, biofouling management methods must be simultaneously cost-effective, environmentally benign, and pose a low risk to human health and safety. The performance of existing and emerging approaches to biofouling management on SSAS was qualitatively evaluated (Table 3) using modified criteria initially developed by Cahill et al. (2019a). Each management method was evaluated against the following performance criteria: Effectiveness (Effective against the broad range of biofouling taxa typically found on artificial surfaces), Biosecurity (The approach is unlikely to exacerbate risks posed by existing marine NIS), and Collateral Effects (The approach is unlikely to impact values such as esthetics, noise, environment, and ethics). For this assessment, three levels - yes, no, and questionable - were used to score whether a method met a criterion under normal operating conditions, which assumed operation by a suitably trained person, appropriate personal protective equipment, and acceptable levels of quality assurance. A fourth criterion, Feasibility (The resource intensiveness, expense, and infrastructure requirements of the approach over the intended lifetime of the SASS), was qualitatively evaluated for each existing and emerging category by industry/infrastructure type (Table 4).

\section{Findings}

Only a third of existing management methods met the Effectiveness, Biosecurity, and Collateral Effects criteria (Table 3). High-pressure washing and mechanical methods (e.g., brushes, discs, or scraping) failed the Biosecurity and Collateral Effects criteria due to risks associated with the potential release of viable propagules, organic material, or chemical contaminants during treatment. The biosecurity criterion could be fulfilled if biofouling species (whether native or non-native) can be released into the local environment without increasing population sizes. By contrast, only one emerging method (AUVs/ROVs) was considered suitable by all three criteria, primarily because of a lack of information to support the assessment of other methods. Although novel coatings and materials were considered effective, efficacy will be dependent on the surface it is applied to, and the environmental conditions experienced on surfaces. Not all surface types will be amenable to coatings, while fouling release coatings, for example, will only be effective if adequate water currents at the site operate in tandem with the coating (Hu et al., 2020).

Encapsulation approaches to biofouling management on SSAS failed two assessment criteria (Table 3). While proven highly effective in response scenarios (e.g., see Atalah et al., 2016), the use of large amounts of encapsulation material, usually plastics, poses environmental risks. Loss of wraps to the wider environment is possible (e.g., during storms), adding to broader plastic pollution and has long term consequences and potential to impact a broad range of organisms (Wayman and Niemann, 2021). The outer surface of encapsulation materials used to date is 
TABLE 3 | Performance evaluation of existing and emerging management methods and approaches to manage static marine infrastructure.

\begin{tabular}{|c|c|c|c|c|c|c|c|c|c|c|c|c|c|c|c|}
\hline \multirow[b]{2}{*}{ Criteria } & \multirow[b]{2}{*}{ Description } & $\begin{array}{c}\text { Mechanical } \\
\text { brushes/ } \\
\text { discs/ } \\
\text { scraping/ } \\
\text { abrasion }\end{array}$ & $\begin{array}{c}\text { High } \\
\text { pressure } \\
\text { washing }\end{array}$ & $\begin{array}{c}\text { Air } \\
\text { exposure }\end{array}$ & Encapsulation & $\begin{array}{c}\text { Traditional } \\
\text { biocidal } \\
\text { coatings }\end{array}$ & $\begin{array}{l}\text { Sprays } \\
\text { \& dips }\end{array}$ & $\begin{array}{l}\text { Novel } \\
\text { coatings } \\
\text { and } \\
\text { materials }\end{array}$ & $\begin{array}{l}\text { AUVs/ } \\
\text { ROVs }\end{array}$ & $\begin{array}{c}\text { Laser } \\
\text { radiation }\end{array}$ & $\begin{array}{l}\text { Bubble } \\
\text { streams }\end{array}$ & $\begin{array}{l}\text { Ultrasound/ } \\
\text { cavitation }\end{array}$ & $\begin{array}{c}\text { Electric } \\
\text { fields }\end{array}$ & Heat & $\begin{array}{c}\text { Biological } \\
\text { control }\end{array}$ \\
\hline & & \multicolumn{7}{|c|}{ Existing } & \multicolumn{7}{|c|}{ Emerging } \\
\hline Effectiveness & $\begin{array}{c}\text { Effective } \\
\text { against the } \\
\text { broad range of } \\
\text { biofouling taxa } \\
\text { typically found } \\
\text { on artificial } \\
\text { surfaces }\end{array}$ & $\checkmark$ & $\checkmark$ & $\checkmark$ & $\checkmark$ & $\checkmark$ & $\checkmark$ & $\checkmark$ & $\checkmark$ & $?$ & $?$ & $?$ & $?$ & $?$ & $\checkmark$ \\
\hline Biosecurity & $\begin{array}{l}\text { The approach } \\
\text { is unlikely to } \\
\text { exacerbate } \\
\text { risks posed by } \\
\text { existing marine } \\
\text { non-indigenous } \\
\text { species }\end{array}$ & $\mathbf{x}$ & $x$ & $\checkmark$ & $\mathrm{x}$ & $\checkmark$ & $\checkmark$ & $\checkmark$ & $\checkmark$ & $\checkmark$ & $\checkmark$ & $\checkmark$ & $\checkmark$ & $\checkmark$ & $\checkmark$ \\
\hline $\begin{array}{l}\text { Collateral } \\
\text { effects }\end{array}$ & $\begin{array}{l}\text { The approach } \\
\text { is unlikely to } \\
\text { impact values } \\
\text { such as } \\
\text { esthetics, } \\
\text { noise, } \\
\text { environment, } \\
\text { and ethics }\end{array}$ & $\mathbf{x}$ & $x$ & $\checkmark$ & $\mathrm{x}$ & $?$ & $\checkmark$ & $\checkmark$ & $\checkmark$ & $?$ & $\checkmark$ & $?$ & $?$ & $\checkmark$ & $\checkmark$ \\
\hline
\end{tabular}

$\checkmark$, yes, meets this criterion; $\boldsymbol{x}$, no; ?, not known/unclear. 
TABLE 4 | Evaluation of the feasibility of existing approaches in relation to resourcing, costs, and infrastructure requirements over their intended lifetime.

\begin{tabular}{|c|c|c|c|c|c|c|}
\hline & Biocidal coatings & $\begin{array}{l}\text { High pressure } \\
\text { washing }\end{array}$ & $\begin{array}{l}\text { Mechanical brushes/ } \\
\text { discs/scraping }\end{array}$ & Sprays and dips & Air exposure & Encapsulation \\
\hline & Continuous & Reactive & Reactive & Reactive & $\begin{array}{l}\text { Reactive/ } \\
\text { Continuous }\end{array}$ & Reactive \\
\hline Aquaculture & $\begin{array}{l}\text { Feasible for nets, } \\
\text { but not effective for } \\
\text { most other } \\
\text { structure types and } \\
\text { would be } \\
\text { impractical or too } \\
\text { costly to apply at a } \\
\text { suitable frequency }\end{array}$ & $\begin{array}{l}\text { Widely used } \\
\text { reactively - } \\
\text { sub-optimal, but } \\
\text { industry perceives } \\
\text { lack of alternatives. } \\
\text { Potential to be } \\
\text { used as a continual } \\
\text { practice }\end{array}$ & $\begin{array}{l}\text { Widely used reactively - } \\
\text { sub-optimal, but industry } \\
\text { perceives lack of } \\
\text { alternatives. Potential to be } \\
\text { used as a continual } \\
\text { practice }\end{array}$ & $\begin{array}{l}\text { Feasible for nets and } \\
\text { shellfish, but not for } \\
\text { structures }\end{array}$ & $\begin{array}{l}\text { Feasible for nets and } \\
\text { buoys, ropes, etc., but not } \\
\text { for larger structures }\end{array}$ & $\begin{array}{l}\text { Not feasible to be } \\
\text { applied as a continuous } \\
\text { approach in a } \\
\text { cost-effective manner }\end{array}$ \\
\hline Energy & $\begin{array}{l}\text { Feasible - is used } \\
\text { extensively in many } \\
\text { sub-sectors, but for } \\
\text { large structures } \\
\text { that are difficult to } \\
\text { remove it would be } \\
\text { impractical or too } \\
\text { costly to apply at a } \\
\text { suitable frequency }\end{array}$ & $\begin{array}{l}\text { Widely used - } \\
\text { sub-optimal, but } \\
\text { industry perceives } \\
\text { lack of alternatives }\end{array}$ & $\begin{array}{l}\text { Widely used - sub-optimal, } \\
\text { but industry perceives lack } \\
\text { of alternatives }\end{array}$ & $\begin{array}{l}\text { Not feasible to apply } \\
\text { regularly, if at all, due to } \\
\text { the scale of structures }\end{array}$ & $\begin{array}{l}\text { Not feasible for } \\
\text { infrastructure where } \\
\text { periodical removal from } \\
\text { water is impractical. } \\
\text { However, could be applied } \\
\text { to oil rigs and other } \\
\text { structures where periodic } \\
\text { removal is possible. } \\
\text { Practical for those } \\
\text { structures in transit }\end{array}$ & $\begin{array}{l}\text { Not feasible to be } \\
\text { applied as a continuous } \\
\text { approach in a } \\
\text { cost-effective manner }\end{array}$ \\
\hline $\begin{array}{l}\text { Ports and } \\
\text { marinas }\end{array}$ & $\begin{array}{l}\text { Not feasible for } \\
\text { most structures } \\
\text { found in these } \\
\text { environments }\end{array}$ & $\begin{array}{l}\text { Not feasible to } \\
\text { apply regularly due } \\
\text { to the scale of } \\
\text { structures }\end{array}$ & $\begin{array}{l}\text { Not feasible to apply } \\
\text { regularly due to the scale of } \\
\text { structures }\end{array}$ & $\begin{array}{l}\text { Not feasible to apply } \\
\text { regularly, if at all, due to } \\
\text { the scale of structures }\end{array}$ & $\begin{array}{l}\text { Not feasible to regularly } \\
\text { remove major infrastructure } \\
\text { from the water for periodic } \\
\text { exposure }\end{array}$ & $\begin{array}{l}\text { Not feasible to be } \\
\text { applied as a continuous } \\
\text { approach in a } \\
\text { cost-effective manner }\end{array}$ \\
\hline
\end{tabular}

also prone to biofouling, meaning inappropriate application can lead to biosecurity risk if biofouling cannot be retained during removal/replacement.

Among the four criteria assessed, Feasibility proved to be the most common hurdle for existing tools (Table 4). Encapsulation methods were considered unfeasible for all SSAS categories for general biofouling prevention or removal, reflecting the limited applicability of this approach to pest eradication or management activities over short timeframes (i.e., days, weeks to months, not years; see Atalah et al., 2016). Structures associated with aquaculture were most amenable to treatment, reflecting their size, the nature of farm activities that often allow structures to be treated when stock are temporarily absent from structures or sites, and possible removal to the water surface or land for treatment. It also reflects the significant amount of mitigation investment by this industry given the direct and quantifiable impacts of biofouling on their operations (Adams et al., 2011; Fitridge et al., 2012; Bloecher and Floerl, 2020). We note, however, that many permanent structures associated with aquaculture (such as anchors and pylons) face the same issues as other SSAS. Ports and marinas posed the greatest feasibility challenge, with none of the existing tools considered feasible to apply at a scale or frequency that would prevent biofouling accumulation. The complexity and large scale of these underwater built environments poses a high barrier to feasible biofouling treatment and the cost of biofouling to operations is not acute unless a particular pest causes damage (e.g., heightened bioerosion) or precipitates other risks (e.g., to amenity use or human health).

There was insufficient information to assess Feasibility of emerging approaches listed in Table 3. In fact, for most emerging approaches there is very limited evidence of testing under realistic conditions, and many unknowns remain regarding compatibility with surface types and environmental conditions, scalability, longevity, cost, and regulatory compliance. Biological control has been used in aquaculture operations for decades (e.g., cleaner wrasse in salmon aquaculture; Gonzalez and de Boer, 2017), but recent studies have shown that control of broad biofouling is challenging and retention of control agents on SSAS will certainly need to be addressed (Atalah et al., 2014). For uniform, flat areas (e.g., marina pontoons), engineering approaches to retain biocontrol agents could be simple, such as the attachment of shelves and barriers to prevent escapes. For larger or more complex structures (e.g., predator nets on finfish farms, wind turbines, oil rigs), biocontrol applications may be unfeasible. AUVs and ROVs have potential for use on flat, uniform areas of large structures (e.g., marina pontoons and the base of wind farms) and on ropes and nets associated with aquaculture (Ohrem et al., 2020).

\section{DISCUSSION}

Our review and assessment highlighted that biofouling management of SSAS is only prioritized when impacts are high and directly affect structural performance, operations, or profitability. There is a relatively strong economic motivation for biofouling management in the aquaculture industry, but biofouling management is rarely, if ever, considered in the design of port and marina infrastructure. The accumulation of biofouling does not usually affect day-to-day operations of ports and marinas and biosecurity risks associated with these facilities 
A

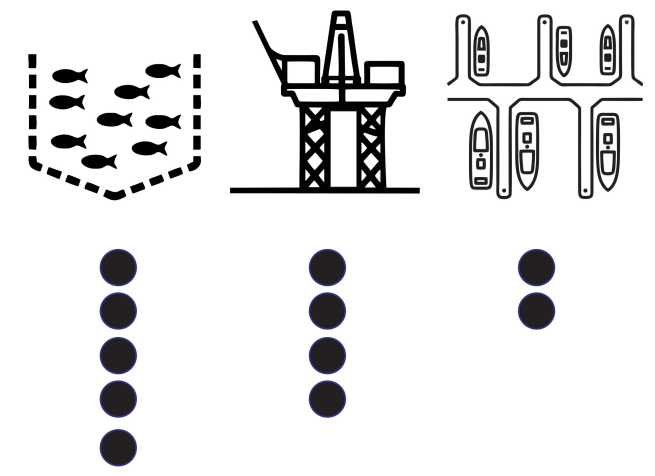

IMPACT TYPE

SERVICE LIFE/LONGEVITY

BIOSECURITY

OPERATIONS

PRODUCTIVITY

ANIMAL HEALTH \& WELFARE

B

\section{COMMERCIAL PRODUCTS \& SERVICES \\ AND BROAD UPTAKE}

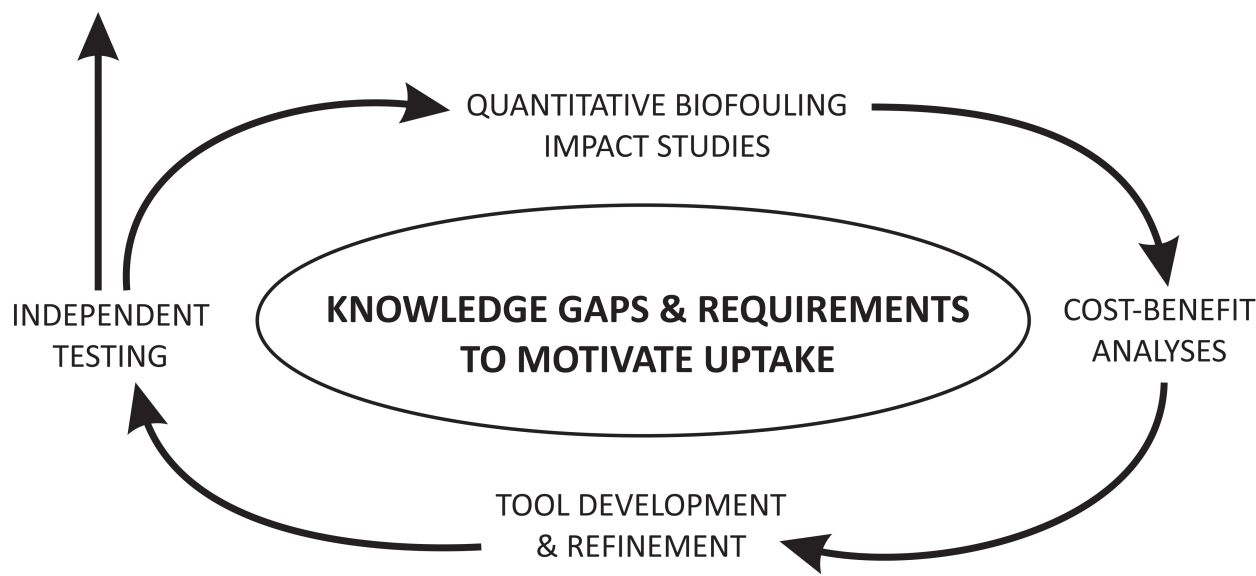

FIGURE 2 | (A) Impact types assigned to the categories of SSAS focused on in this review: aquaculture, energy production, and port and marina infrastructure, and (B) knowledge gaps and requirements to facilitate or motivate the uptake of existing and emerging biofouling management tools. Impact types assigned in panel (A) are based on normal operations and could change during a biosecurity response (e.g., closure of a marina for treatment).

(establishment and proliferation of NIS) are not typically managed by the facility operators. For the energy and ports and marina industries, the Feasibility criterion was the biggest implementation hurdle, as many of the present-day tools would be cost-prohibitive or impractical to apply at scale or to SSAS types associated with these industries. Nonetheless, there are motivations for proactive and sustained biofouling management for most maritime infrastructure that could reduce chronic impacts of biofouling to improve the longevity or function of structures and improve environmental and biosecurity outcomes associated with the built environment. It is noteworthy that $75 \%$ of existing management methods were categorized as "reactive," applied after biofouling has accumulated or has become problematic (Table 4). Only biocidal coatings, non-biocidal coatings, and desiccation (i.e., the FlipFarm approach used in oyster farming ${ }^{6}$ accessed June 25, 2020) provide proactive and continuous protection from biofouling.

${ }^{6} \mathrm{https}: / /$ www.flipfarm.co.nz
By contrast, all emerging methods represented proactive and continuous approaches, highlighting that innovation in this field is trending toward preventing problems rather than responding to them.

Antifouling coatings in conjunction with marine growth protection systems represent the primary line of defense used by vessels to prevent colonization and growth of biofouling on submerged laminar surfaces and internal seawater systems, respectively (International Maritime Organization [IMO], 2011; Georgiades et al., 2018; Davidson et al., in press). These antifouling technologies have been optimized for operational vessels and as such are not directly transferable to static infrastructure. Foul-release coatings are only effective on vessel surfaces that provide shear stress above threshold values that prevents adherence of biofouling organisms (Larsson et al., 2016; Georgiades et al., 2018). Similarly, self-polishing and soluble-matrix biocidal coatings rely on water movement to continually erode thin layers of surface coatings to expose fresh biocide (Xie et al., 2019). The ecological impacts of biocidal 
coatings include continual release of broad spectrum and persistent biocides (Amara et al., 2018; Richir et al., 2021) which are regulated in many jurisdictions (e.g., New Zealand Environmental Protection Authority, 2013). Given their functional limitations in static environments and role in chemical pollution, broad use of biocidal coatings on SASS is questionable.

Advances in biofouling management in the shipping industry are gradually moving toward less reliance on biocides and untreated discharges to marine systems with persistent environmental effects. For example, antifouling coatings used on commercial ships have shifted away from highly effective but highly toxic TBT-based products to less-toxic formulations, as well as phasing out several co-biocides (International Maritime Organization [IMO], 2001, New Zealand Environmental Protection Authority, 2013). Motivations for biofouling management for vessels began as operational (e.g., improved hydrodynamic performance, Schultz et al., 2011), but over time, legislation has added biosecurity considerations and responsibilities to bear on the industry (International Maritime Organization [IMO], 2011; Georgiades et al., 2020a). Regulatory requirements are driving attention and improvements in biofouling management on vessels for surfaces that do not incur significant hydrodynamic or operational penalties (Davidson et al., 2016). This is driving research and development toward biofouling management of heterogeneous surfaces and hydrodynamically complex vessel surfaces that may have carryover benefit for SSAS management in future. A similar trend has improved ballast water management over time, including ballast exchange and the more recent installation of treatment systems, derived from a history of municipal or land-based water treatment, to manage biosecurity risks (Balaji et al., 2014; Davidson et al., 2017).

Unlike established operational and legislative biofouling standards for vessels, standards for SSAS are less developed and largely exist as consent or permitting conditions for an activity (e.g., a requirement to keep marine farming structures free of listed pest species), as a safety consideration (e.g., suction pressure for intakes) or, more broadly, as industry guidelines or best practice (e.g., Australia's Biofouling Management Guidelines for the Petroleum Production and Exploration Industry). Relatively last-minute responses to offshore platform movements, usually on a case-by-case basis, underscores how little forethought is applied to biofouling management for these structures (Wanless et al., 2010; Hopkins et al., 2011). In the absence of regulation, decisions to manage biofouling proactively or reactively on SSAS will ultimately focus on net benefits in terms of cost. Determining whether SSAS management measures are cost effective is straightforward where direct benefits of managing biofouling accumulation can be quantified. For example, reduced biofouling could lead to increased yield or a superior product from a marine farm (Bloecher and Floerl, 2020). For a drilling rig or power plant, a greater number of operational days per year could be realized if delays or temporary shutdowns associated with biofouling impacts are avoided. Drilling rigs could also benefit from freedom to operate in regions that have biosecurity measures associated with biofouling management
(Scott et al., 2017). By contrast, for some categories of SSAS, such as marinas and port infrastructure (pontoons and pilings, etc.), the cost of biofouling impact is usually not considered, or measured in decades, or the impacts are indirect. This does not mean that costs or benefits cannot be quantified or modeled. For example, the multi-year or decadal cost of structure degradation under biofouling pressure can be combined with indirect costs associated with heightened fouling rates on vessels and the costs associated with NIS incursion and proliferation at these hubs of vessel activity.

Likewise, boaters have voiced concern and frustration that levels of biofouling in marina environments often vastly exceeds the levels desirable or required for vessels (Newton, 2019). There is a growing body of work that describes these broader impacts, their costs, and the management responses that are enacted to address them (Bax et al., 2002; Coutts and Forrest, 2007; Groeneveld et al., 2018). An additional advantage of costbenefit analyses is that they can be used to determine the "break even" management cost ("external cost") per unit area of SSAS, below which a net positive benefit is achieved. This can be used to inform the design, material types, and technology needed for various structure types. For some structures, it will be a challenge to develop management approaches within cost-benefit parameters that meet the performance criteria considered in this review without factoring indirect benefits into decision making.

The performance evaluation framework applied in this study was used to identify capabilities and limitations of existing and emerging biofouling management methods. The range of data and information available to assess methods against criteria varies dramatically, sometimes including marketing material, personal anecdotes, and "educated guesses" because robust testing data or evidence of performance is lacking for many methods. This lack of evidence is arguably the largest hurdle for uptake by end users. To facilitate uptake, independent testing to verify effectiveness, safety, and feasibility - such as type approval processes that occur in many industries, including ballast water treatment - is paramount (Figure 2). Such system testing is widespread and for our Biosecurity criterion, technical advice to inform evaluation procedures for in-water cleaning systems to remove or treat vessel biofouling have been developed and demonstrated (Morrisey et al., 2015; Growcott et al., 2019; Tamburri et al., 2020) and could be adapted for SSAS applications where applicable.

\section{Concluding Comments}

This review highlights that the arsenal of tools currently available to manage marine biofouling on SSAS lacks proactive options to limit the associated consequences to infrastructure and the environment. For SSAS that can be removed from the water without too much difficulty, environmentally friendly antifouling coatings hold promise as a cost-effective approach. However, for SSAS that are difficult or impossible to remove for maintenance, novel approaches are needed that can be applied prior to structure deployment or constantly while the structure is in water. Environmental and operational benefits can be realized if biofouling management of static infrastructure can be applied in a cost-efficient manner, with innovation in emerging approaches 
trending toward preventive or continuous management rather than reactive cleaning of surfaces. More holistic cost-benefit analyses that include indirect costs of inaction and benefits of biofouling management will provide a stronger framework for implementation using cost estimates that more accurately reflect the broad effects of biofouling on SSAS throughout the seascape.

\section{AUTHOR CONTRIBUTIONS}

$\mathrm{GH}$ developed the original concept with subsequent refinement by all other authors. $\mathrm{GH}$ and $\mathrm{PC}$ wrote the

\section{REFERENCES}

Adams, C. M., Shumway, S. E., Whitlatch, R. B., and Getchis, T. (2011). Biofouling in marine molluscan shellfish aquaculture: a survey assessing the business and economic implications of mitigation. J. World Aquac. Soc. 42, 242-252. doi: 10.1111/j.1749-7345.2011.00460.x

Airoldi, L., Beck, M. W., Firth, L. B., Bugnot, A. B., Steinberg, P. D., and Dafforn, K. A. (2021). Emerging solutions to return nature to the urban ocean. Ann. Rev. Ma.r Sci. 13, 445-477. doi: 10.1146/annurev-marine-032020-020015

Airoldi, L., Turon, X., Perkol-Finkel, S., and Rius, M. (2015). Corridors for aliens but not for natives: effects of marine urban sprawl at a regional scale. Divers. Distrib. 21, 755-768.

Almeida, J. R., Moreira, J., Pereira, D., Pereira, S., Antunes, J., Palmeira, A., et al. (2018). Potential of synthetic chalcone derivatives to prevent marine biofouling. Sci. Total Environ. 643, 98-106. doi: 10.1016/j.scitotenv.2018.06.169

Amara, I., Miled, W., Slama, R. B., and Ladhari, N. (2018). Antifouling processes and toxicity effects of antifouling paints on marine environment. A review. Environ. Toxicol. Pharmacol. 57, 115-130. doi: 10.1016/j.etap.2017.12.001

Ammon, U., Swift, L., Brand, S., Jeff, A., and Swift, S. (2019). Review of in-Water Hull Encapsulation and Enclosure Treatments for Eliminating Marine Biofouling. Wellington: Ministry of Primary Industries.

Anderson, L. (2005). California's reaction to Caulerpa taxifolia: a model for invasive species rapid response. Biol. Invasions 7, 1003-1016. doi: 10.1007/s10530-0043123-z

Arnott, J., Wu, A. H., Vucko, M. J., and Lamb, R. N. (2014). Marine antifouling from thin air. Biofouling 30, 1045-1054. doi: 10.1080/08927014.2014.967687

Atalah, J., Brook, R., Cahill, P., Fletcher, L. M., and Hopkins, G. A. (2016). It's a wrap: encapsulation as a management tool for marine biofouling. Biofouling 32, 277-286. doi: 10.1080/08927014.2015.1137288

Atalah, J., Fletcher, L. M., Davidson, I. C., South, P. M., and Forrest, B. M. (2020). Artificial habitat and biofouling species distributions in an aquaculture seascape. Aquac. Environ. Interact. 12, 495-509. doi: 10.3354/aei00380

Atalah, J., Hopkins, G. A., and Forrest, B. M. (2013). Augmentative biocontrol in natural marine habitats: persistence, spread and non-target effects of the sea urchin Evechinus chloroticus. PLoS One 8:e80365. doi: 10.1371/journal.pone. 0080365

Atalah, J., Newcombe, E. M., Hopkins, G. A., and Forrest, B. M. (2014). Potential biocontrol agents for biofouling on artificial structures. Biofouling 30, 9991010. doi: 10.1080/08927014.2014.956734

Azemar, F., Faÿ, F., Réhel, K., and Linossier, I. (2015). Development of hybrid antifouling paints. Prog. Org. Coat. 87, 10-19. doi: 10.1016/j.porgcoat.2015.04. 007

Bakker, J. A., Paetzold, C., Quijon, P. A., and Davidson, J. (2011). The use of food grade oil in the prevention of vase tunicate fouling on mussel aquaculture gear. Manag. Biol. Invasions 2, 15-25. doi: 10.3391/mbi.2011.2.1.02

Balaji, R., Yaakob, O., and Koh, K. K. (2014). A review of developments in ballast water management. Environ. Rev. 22, 298-310. doi: 10.1139/er-2013-0073

Bannister, J., Sievers, M., Bush, F., and Bloecher, N. (2019). Biofouling in marine aquaculture: a review of recent research and developments. Biofouling 35, 631-648. doi: 10.1080/08927014.2019.1640214

Bax, N., Hayes, K., Marshall, A., Parry, D., and Thresher, R. (2002). "Man-made marinas as sheltered islands for alien marine organisms: establishment and first draft of the manuscript. All authors contributed to manuscript's preparation, revision, and read and approved the submitted version.

\section{FUNDING}

This review was funded by the New Zealand's Ministry of Business, Innovation and Employment (investment CAWX1904 - A toolbox to underpin and enable tomorrow's marine biosecurity system).

eradication of an alien invasive marine species," in Turning the Tide: The Eradication of invasive species, eds C. R. Veitch and M. N. Clout (Switzerland: International Union for Conservation of Nature Invasive Species Specialist Group), 26-39.

Bell, A., Phillips, S., Denny, C., Georgiades, E., and Kluza, D. (2011). Risk Analysis: Vessel Biofouling. Wellington: Ministry of Agriculture and Forestry Biosecurity New Zealand.

Blackwood, D. J., Lim, C. S., Teo, S. L. M., Hu, X., and Pang, J. (2017). Macrofouling induced localized corrosion of stainless steel in Singapore seawater. Corros. Sci. 129, 152-160. doi: 10.1016/j.corsci.2017.10.008

Bloecher, N., and Floerl, O. (2020). Towards cost-effective biofouling management in salmon aquaculture: a strategic outlook. Rev. Aquac. 13, 783-795. doi: 10. 1111/raq. 12498

Bloecher, N., Floerl, O., and Sunde, L. M. (2015). Amplified recruitment pressure of biofouling organisms in commercial salmon farms: potential causes and implications for farm management. Biofouling 31, 163-172. doi: 10.1080/ 08927014.2015.1012713

Braithwaite, R. A., Carrascosa, M. C. C., and McEvoy, L. A. (2007). Biofouling of salmon cage netting and the efficacy of a typical copper-based antifoulant. Aquaculture 262, 219-226. doi: 10.1016/j.aquaculture.2006.11.027

Bugnot, A. B., Mayer-Pinto, M., Airoldi, L., Heery, E. C., Johnston, E. L., Critchley, L. P., et al. (2020). Current and projected global extent of marine built structures. Nat. Sustain. 4, 33-41. doi: 10.1038/s41893-020-00595-1

Bullard, S. G., Shumway, S. E., and Davis, C. V. (2010). The use of aeration as a simple and environmentally sound means to prevent biofouling. Biofouling 26, 587-593. doi: 10.1080/08927014.2010.496038

Bulleri, F., and Chapman, M. G. (2010). The introduction of coastal infrastructure as a driver of change in marine environments. J. Appl. Ecol. 47, 26-35. doi: 10.1111/j.1365-2664.2009.01751.x

Cahill, P., Tait, L., Floerl, O., Bates, T., Growcott, A., and Georgiades, E. (2019b). A portable thermal system for reactive treatment of biofouled internal pipework on recreational vessels. Mar. Pollut. Bull. 139, 65-73. doi: 10.1016/j.marpolbul. 2018.12.032

Cahill, P., Hickey, C., Lewis, P., Tait, L., and Floerl, O. (2019a). Treatment Agents for Biofouling in Internal Pipework of Recreational Vessels. Ministry for Primary Industries Technical Paper No. 2019/03. Wellington: Ministry for Primary Industries.

Cahill, P. L., Atalah, J., Cunningham, S., Day, A., Fletcher, L. M., South, P., et al. (2021). Acetic acid immersion - a reactive pest treatment for bivalve aquaculture. Aquaculture 533:736173. doi: 10.1016/j.aquaculture.2020.736173

California Code of Regulations (2017). Biofouling Management to Minimize the Transfer of Nonindigenous Species from Vessels Arriving at California Ports. California, CA: California Code of Regulations.

Callow, J. A., and Callow, M. E. (2011). Trends in the development of environmentally friendly fouling-resistant marine coatings. Nat. Commun. 2, 1-10. doi: 10.1038/ncomms1251

Capel, K. C. C., Creed, J., Kitahara, M. V., Chen, C. A., and Zilberberg, C. (2019). Multiple introductions and secondary dispersion of Tubastraea spp. in the Southwestern Atlantic. Sci. Rep. 9:13978. doi: 10.1038/s41598-019-50442-3

Carballeira Braña, C. B., Cerbule, K., Senff, P., and Stolz, I. K. (2021). Towards environmental sustainability in marine finfish aquaculture. Front. Mar. Sci. 8:666662. doi: 10.3389/fmars.2021.666662 
Carman, M., Estes, T., Feinberg, A., Schumacher, J., Wilkerson, W., Wilson, L., et al. (2006). Engineered antifouling microtopographies - correlating wettability with cell attachment. Biofouling 22, 11-21. doi: 10.1080/08927010500484854

Carteau, D., Vallée-Réhel, K., Linossier, I., Quiniou, F., Davy, R., Compère, C., et al. (2014). Development of environmentally friendly antifouling paints using biodegradable polymer and lower toxic substances. Prog. Org. Coat. 77, 485493. doi: 10.1016/j.porgcoat.2013.11.012

Carve, M., Scardino, A., and Shimeta, J. (2019). Effects of surface texture and interrelated properties on marine biofouling: a systematic review. Biofouling 35 , 597-617. doi: 10.1080/08927014.2019.1636036

Chaabane, P., Austin, C., Isaksson, D., Weigenand, O., and Ohlauson, C. (2019). Application of Biotechnology in Antifouling Solutions for Hard Fouling Prevention. Available online at: https://selektope.com (accessed March 23, 2021).

Chapman, M. G. (2003). Paucity of mobile species on constructed seawalls: effects of urbanization on biodiversity. Mar. Ecol. Prog. Ser. 264, 21-29. doi: 10.3354/ MEPS264021

Cho, S. H., White, S. R., and Braun, P. V. (2009). Self-healing polymer coatings. Adv. Mater. 21, 645-649. doi: 10.1002/adma.200802008

Coolen, J. W., Boon, A. R., Crooijmans, R., Van Pelt, H., Kleissen, F., Gerla, D., et al. (2020). Marine stepping-stones: connectivity of Mytilus edulis populations between offshore energy installations. Mol. Ecol. 29, 686-703. doi: 10.1111/mec. 15364

Costa, R., Moggridge, G. D., and Aldridge, D. C. (2012). “Improved mussel control through microencapsulated BioBullets," in Operational and Environmental Consequences of Large Industrial Cooling Water Systems, eds S. Rajagopal, H. A. Jenner, and V. P. Venugopalan (Berlin: Springer), 273-286.

Costello, K. E., Lynch, S. A., McAllen, R., O’Riordan, R. M., and Culloty, S. C. (2021). The role of invasive tunicates as reservoirs of molluscan pathogens. Biol. Invasions 23, 641-655. doi: 10.1007/s10530-020-02392-5

Coutts, A. D. M., and Forrest, B. M. (2007). Development and application of tools for incursion response: lessons learned from the management of the fouling pest Didemnum vexillum. J. . Exp. Mar. Bio. Ecol. 342, 154-162. doi: 10.1016/j.jembe. 2006.10.042

Coutts, A. D. M., Valentine, J. P., Edgar, G. J., Davey, A., and Burgess-Wilson, B. (2010). Removing vessels from the water for biofouling treatment has the potential to introduce mobile non-indigenous marine species. Mar. Pollut. Bull. 60, 1533-1540. doi: 10.1016/j.marpolbul.2010.04.015

Cunningham, S., Teirney, L., Brunton, J., McLeod, R., Bowman, R., Richards, D., et al. (2019). Mitigating the threat of invasive marine species to Fiordland: New Zealand's first pathway management plan. Manag. Biol. Invasions 10, 690-708. doi: 10.3391/mbi.2019.10.4.07

Dafforn, K. A., Glasby, T. M., Airoldi, L., Rivero, N. K., Mayer-Pinto, M., and Johnston, E. L. (2015). Marine urbanization: an ecological framework for designing multifunctional artificial structures. Front. Ecol. Environ 13:82-90. doi: 10.1890/140050

Dafforn, K. A., Lewis, J. A., and Johnston, E. L. (2011). Antifouling strategies: history and regulation, ecological impacts and mitigation. Mar. Pollut. Bull. 62, 453-465. doi: 10.1016/j.marpolbul.2011.01.012

Davidson, I., Cahill, P., Hinz, A., Kluza, D., Scianni, C., and Georgiades, E. (in press). A review of biofouling of ships' internal seawater systems. Front. Mar. Sci.

Davidson, I., Scianni, C., Hewitt, C., Everett, R., Holm, E., Tamburri, M., et al. (2016). Mini-review: assessing the drivers of ship biofouling managementaligning industry and biosecurity goals. Biofouling 32, 411-428. doi: 10.1080/ 08927014.2016.1149572

Davidson, I. C., Minton, M. S., Carney, K. J., Miller, A. W., and Ruiz, G. M. (2017). Pioneering patterns of ballast treatment in the emerging era of marine vector management. Mar. Policy 78, 158-162.

de Campos, B. G., Figueiredo, J., Perina, F., Abessa, D. M. D. S., Loureiro, S., and Martins, R. (2021). Occurrence, effects and environmental risk of antifouling biocides (EU PT21): are marine ecosystems threatened? Crit. Rev. Environ. Sci. Technol. [Epub ahead of print]. doi: 10.1080/10643389.2021.1910003

De Mesel, I., Kerckhof, F., Norro, A., Rumes, B., and Degraer, S. (2015). Succession and seasonal dynamics of the epifauna community on offshore wind farm foundations and their role as stepping stones for non-indigenous species. Hydrobiologia 756, 37-50. doi: 10.1007/s10750-014-2157-1 de Nys, R., and Guenther, J. (2009). "The impact and control of biofouling in marine finfish aquaculture," in Advances in Marine Antifouling Coatings and Technologies, eds C. Hellio and D. Yebra (Cambridge, MA: Woodhead Publishing Ltd), 177-221.

de Nys, R., and Ison, O. (2004). Evaluation of Antifouling Products Developed for the Australian Pearl Industry. Final Report to the Fisheries Research and Development Corporation Project No 2000/254. Townsville: James Cook University, 1-114.

Denny, C. M. (2008). Development of a method to reduce the spread of the ascidian Didemnum vexillum with aquaculture transfers. ICES J. Mar. Sci. 65, 805-810. doi: 10.1093/icesjms/fsn039

Do, C. N. (1991). Apparatus for the Combatting of Marine Growth on Offshore Structures. U. S. Patent 5,026,212. London: IEV International Pty Ltd.

Dürr, S., and Watson, D. I. (2010). "Biofouling and antifouling in aquaculture," in Biofouling, eds S. Dürr and J. C. Thomason (Hoboken, NJ: Blackwell Publishing Limited).

Eilenberg, J., Hajek, A., and Lomer, C. (2001). Suggestions for unifying the terminology in biological control. BioControl 46, 387-400. doi: 10.1023/A: 1014193329979

Enright, C., Krailo, D., Staples, L., Smith, M., Vaughan, C., Ward, D., et al. (1984). Biological control of fouling algae in oyster aquaculture. J. Shellfish Res. 3, 41-44.

Eom, S. H., Kim, S. S., and Lee, J. B. (2020). Assessment of anti-corrosion performances of coating systems for corrosion prevention of offshore wind power steel structures. Coatings 10:970. doi: 10.3390/coatings10100970

Erkinharju, T., Dalmo, R. A., Hansen, M., and Seternes, T. (2020). Cleaner fish in aquaculture: review on diseases and vaccination. Rev. Aquac. 13, 189-237. doi: $10.1111 /$ raq. 12470

Firth, L. B., Knights, A. M., Bridger, D., Evans, A. J., Mieszkowska, N., Moore, P. J., et al. (2016). Ocean sprawl: challenges and opportunities for biodiversity management in a changing world. Oceanogr. Mar. Biol. 54, 193-269. doi: 10. 1201/9781315368597-9

Fitridge, I., Dempster, T., Guenther, J., and de Nys, R. (2012). The impact and control of biofouling in marine aquaculture: a review. Biofouling 28, 649-669. doi: 10.1080/08927014.2012.700478

Floerl, O., Atalah, J., Bugnot, A. B., Chandler, M., Dafforn, K. A., Floerl, L. F., et al. (in press). A global model to forecast coastal hardening and mitigate associated socioecological risks. Nat. Sustain. doi: 10.1038/s41893-021-00780-w

Floerl, O., and Inglis, G. I. (2003). Boat harbour design can exacerbate hull fouling. Austral. Ecol. 28, 116-127. doi: 10.1007/s00267-004-0193-8

Floerl, O., Inglis, G. J., Dey, K., and Smith, A. (2009). The importance of transport hubs in stepping-stone invasions. J. Appl. Ecol. 46, 37-45. doi: 10.1111/j.13652664.2008.01540.x

Forrest, B. M., and Blakemore, K. A. (2006). Evaluation of treatments to reduce the spread of a marine plant pest with aquaculture transfers. Aquaculture 257, 333-345. doi: 10.1016/j.aquaculture.2006.03.021

Foster, B. A., and Willan, R. C. (1979). Foreign barnacles transported to New Zealand on an oil platform. N. Z. J. Mar Freshw. Res. 13, 143-149.

Georgiades, E., Fraser, R., and Jones, B. (2016). Options to Strengthen on-Farm Biosecurity Management for Commercial and Non-Commercial Aquaculture. Technical Paper No: 2016/47. Wellington: New Zealand's Ministry for Primary Industries.

Georgiades, E., Fraser, R., and Jones, B. (2020a). Technical Guidance Document: High Level Biosecurity Management Plans Finfish (Land-Based and Ocean Facilities). Biosecurity New Zealand Technical Paper No: 2020/07. Wellington: Ministry of Primary Industries.

Georgiades, E., Kluza, D., Bates, T., Lubarsky, K., Brunton, J., Growcott, A., et al. (2020b). Regulating vessel biofouling to support New Zealand's marine biosecurity system - a blue print for evidence-based decision making. Front. Mar. Sci. 7:390. doi: 10.3389/fmars.2020.00390

Georgiades, E., Growcott, A., and Kluza, D. (2018). Technical Guidance on Biofouling Management for Vessels Arriving to New Zealand. Ministry for Primary Industries Technical Paper No. 2018/07. Wellington: Ministry for Primary Industries.

Georgiades, E., and Kluza, D. (2017). Evidence-based decision making to underpin the thresholds in New Zealand's CRMS: biofouling on vessels arriving to New Zealand. J. Mar. Sci. Technol. 51, 76-88. doi: 10.4031/MTSJ.51.2.5 
Georgiades, E., Scianni, C., Davidson, I., Tamburri, M. N., First, M. R., Ruiz, G., et al. (2021). The role of vessel biofouling in the translocation of marine pathogens: management considerations and challenges. Front. Mar. Sci. 8:435. doi: 10.3389/fmars.2021.660125

Gibson, A. G., and Arun, S. (2016). "Composite materials in the offshore industry," in Reference Module in Materials Science and Materials Engineering, ed. A. G. Gibson (Amsterdam: Elsevier).

Giovannini, R. (2017). Venice and MOSE: Story of a Failure. Accessed at: https:/www.lastampa.it/esteri/la-stampa-in-english/2017/10/12/news/veniceand-mose-story-of-a-failure- 1.34401212 (accessed March 19, 2021).

Glasby, T. M., Connell, S. D., Holloway, M. G., and Hewitt, C. L. (2007). Nonindigenous biota on artificial structures: could habitat creation facilitate biological invasions? Mar. Biol. 151, 887-895. doi: 10.1007/s00227-006-0552-5

Gonzalez, E. B., and de Boer, F. (2017). The development of the Norwegian wrasse fishery and the use of wrasses as cleaner fish in the salmon aquaculture industry. Fish. Sci. 83, 661-670. doi: 10.1007/s12562-017-1110-4

Gormley, K., McLellan, F., McCabe, C., Hinton, C., Ferris, J., Kline, D. I., et al. (2018). Automated image analysis of offshore infrastructure marine biofouling. J. Mar. Sci. Eng. 6:2. doi: 10.3390/jmse6010002

Groeneveld, R. A., Bartelings, H., Börger, T., Bosello, F., Buisman, E., Delpiazzo, E., et al. (2018). Economic impacts of marine ecological change: review and recent contributions of the VECTORS project on European marine waters. Estuar. Coast. Shelf Sci. 201, 152-163. doi: 10.1016/j.ecss.2016.04.002

Growcott, A., Kluza, D., and Georgiades, E. (2017). In-water systems to reactively manage biofouling in sea chests and internal pipework. Mar. Technol. Soc. J. 51, 89-104. doi: 10.4031/MTSJ.51.2.3

Growcott, A., Kluza, D., and Georgiades, E. (2019). Technical Advice: Evaluation of In-Water Systems to Reactively Treat or Remove Biofouling Within Vessel Internal Niche Areas. Wellington: Ministry for Primary Industries.

Gu, Y., Yu, L., Mou, J., Wu, D., Xu, M., Zhou, P., et al. (2020). Research strategies to develop environmentally friendly marine antifouling coatings. Mar. Drugs 18:371. doi: 10.3390/md18070371

Guenther, J., Fitridge, I., and Misimi, E. (2011). Potential antifouling strategies for marine finfish aquaculture: the effects of physical and chemical treatments on the settlement and survival of the hydroid Ectopleura larynx. Biofouling 27, 1033-1042. doi: 10.1080/08927014.2011.627092

Guo, S., Khoo, B. C., Teo, S. L., and Lee, H. P. (2013). The effect of cavitation bubbles on the removal of juvenile barnacles. Colloids Surf. B. 109, 219-227. doi: 10.1016/j.colsurfb.2013.03.046

Guo, S., Lee, H. P., and Khoo, B. C. (2011). Inhibitory effect of ultrasound on barnacle (Amphibalanus amphitrite) cyprid settlement. J. Exp. Mar. Bio. Ecol. 409, 253-258. doi: 10.1016/j.jembe.2011.09.006

Hodson, S. L., Burke, C. M., and Bissett, A. P. (2000). Biofouling of fishcage netting: the efficacy of a silicone coating and the effect of netting colour. Aquaculture 184, 277-290. doi: 10.1016/S0044-8486(99)00328-2

Hodson, S. L., Lewis, T. E., and Burke, C. M. (1997). Biofouling of fishcage netting: efficacy and problems of in situ cleaning. Aquaculture 152, 77-90.

Hopkins, G. A., and Forrest, B. M. (2010). Challenges associated with pre-border management of biofouling on oil rigs. Mar. Pollut. Bull. 60, 1924-1929. doi: 10.1016/j.marpolbul.2010.07.015

Hopkins, G. A., Forrest, B. M., and Coutts, A. D. M. (2010). The effectiveness of rotating brush devices for management of vessel hull fouling. Biofouling 26, 555-566. doi: 10.1080/08927014.2010.494330

Hopkins, G. A., Forrest, B. M., Jiang, W., and Gardner, J. P. A. (2011). Successful eradication of a non-indigenous marine bivalve from a subtidal soft sediment environment. J. Appl. Ecol. 48, 424-431. doi: 10.1111/j.1365-2664.2010.01941.x

Hopkins, G. A., Gilbertson, F., Floerl, O., Pine, M., Casanovas, P., and Cahill, P. (2021). Continuous bubble streams for controlling biofouling on static artificial structures. PeerJ 9:e11323. doi: 10.7717/peerj.11323

Hopkins, G. A., Prince, M., Cahill, P. L., Fletcher, L. M., and Atalah, J. A. (2016). Desiccation as a mitigation tool to manage biofouling risks: trials on temperate taxa to elucidate factors influencing mortality rates. Biofouling 32, 1-11. doi: 10.1080/08927014.2015.1115484

Howard, A. E. (1994). The possibility of long distance transmission of Bonamia by fouling on boat hulls. Bull. Eur. Assoc. Fish Pathol. 14, 211-212.

Hu, P., Xie, Q., Ma, C., and Zhang, G. (2020). Silicone-based fouling-release coatings for marine antifouling. Langmuir 36, 2170-2183. doi: 10.1021/acs. langmuir.9b03926
Hunt, L., Chadderton, L., Stuart, M., Cooper, S., and Carruthers, M. (2009). Results of an Attempt to Control and Eradicate Undaria Pinnatifida in Southland, New Zealand, April 1997 - November 2004. Amsterdam: Elsevier.

Iacarella, J. C., Davidson, I. C., and Dunham, A. (2019). Biotic exchange from movement of 'static' maritime structures. Biol. Invasions 21, 1131-1141. doi: 10.1007/s10530-018-1888-8

Inglis, G., Floerl, O., and Woods, C. (2012). Scenarios of Vessel Biofouling Risk and Their Management. MAF research project RFP11832. Wellington: Ministry of Agriculture and Forestry, 41-93.

International Maritime Organization [IMO] (2001). International Convention on the Control of Harmful Anti-Fouling Systems On Ships. London: IMO.

International Maritime Organization [IMO] (2004). International Convention for the Control, and Management of. (Ships')Ballast Water and Sediments. London: International Maritime Organization.

International Maritime Organization [IMO] (2011). Guidelines for The Control, and Management of Ships.' (Biofouling)to Minimize the Transfer of Invasive Aquatic Species. London: International Maritime Organization.

International Organization for Standardization [ISO] (2016). ISO 12944-5 Paints, and Varnishes. (-)Corrosion Protection of Steel Structures by Protective Paint Systems-Part 5: Protective paint systems. Geneva: ISO.

Jenner, H. A., Whitehouse, J. W., Taylor, C. J., and Khalanski, M. (1998). Cooling water management in European power stations: biology and control of fouling. Hydroécol. Appl. 1, 225-265.

Klijnstra, J., Zhang, X., van der Putten, S., and Röckmann, C. (2017). “Technical risks of offshore structures," in Aquaculture Perspective of Multi-Use Sites in the Open Ocean, eds B. H. Buck and R. Langan (Switzerland: Springer).

Kostenko, V. V., Yu Bykanova, A., and Yu Tolstonogov, A. (2019). Underwater robotics complex for inspection and laser cleaning of ships from biofouling. IOP Conf. Ser. Earth Environ. Sci. 272:022103. doi: 10.1088/1755-1315/272/2/ 022103

Larsson, L., Vandeleur, H. M., Nyden, M., and Styan, C. A. (2016). "No harm, no foul? Expert views on the future direction of marine antibiofouling technologies," in Chemeca 2016: Chemical Engineering - Regeneration, Recovery and Reinvention, ed. T. Williams (Melbourne: Engineers Australia), 995-1006.

Legg, M., Yucel, M. K., Garcia de Carellan, I., Kappatos, V., Selcuk, C., and Gan, T. H. (2015). Acoustic methods for biofouling control: a review. Ocean Eng. 103, 237-247. doi: 10.1016/j.oceaneng.2015.04.070

Li, C., Wang, G., Chen, K., Yun, F., and Wang, L. (2020). Mechanical analysis of a scraping method to remove attached barnacles. J. Mar. Sci. Eng. 8:150. doi: $10.3390 /$ jmse 8030150

Li, Y., and Ning, C. (2019). Latest research progress of marine microbiological corrosion and bio-fouling, and new approaches of marine anti-corrosion and anti-fouling. Bioact. Mater. 4, 189-195. doi: 10.1016/j.bioactmat.2019. 04.003

Li, Z., and Guo, Z. (2019). Bioinspired surfaces with wettability for antifouling application. Nanoscale 11, 22636-22663. doi: 10.1039/C9NR05870B

Liu, L. L., Wu, C. H., and Qian, P. Y. (2020). Marine natural products as antifouling molecules-a mini-review (2014-2020). Biofouling 36, 1210-1226. doi: 10.1080/ 08927014.2020 .1864343

Lodeiros, C., and García, N. (2004). The use of sea urchins to control fouling during suspended culture of bivalves. Aquaculture 231, 293-298. doi: 10.1016/j. aquaculture.2003.10.022

Lowen, J. B., Deibel, D., McKenzie, C. H., Couturier, C., and DiBacco, C. (2016). Tolerance of early life-stages in Ciona intestinalis to bubble streams and suspended particles. Manag. Biol. Invasions 7, 157-165. doi: 10.3391/mbi.2016. 7.2.03

Loxton, J., Macleod, A. K., Nall, C. R., McCollin, T., Machado, I., Simas, T., et al. (2017). Setting an agenda for biofouling research for the marine renewable energy industry. Int. J. Mar. Energy 19, 292-303. doi: 10.1016/j.ijome.2017.08. 006

Macleod, A. K., Stanley, M. S., Day, J. G., and Cook, E. J. (2016). Biofouling community composition across a range of environmental conditions and geographical locations suitable for floating marine renewable energy generation. Biofouling 32, 261-276. doi: 10.1080/08927014.2015.1136822

Malerba, M. E., White, C. R., and Marshall, D. J. (2019). The outsized trophic footprint of marine urbanization. Front. Ecol. Environ. 17, 400-406. doi: 10. 1002/fee.2074 
McDonald, J. I, Wellington, C. M., Coupland, G. T., Pedersen, D., Kitchen, B., Bridgwood, S. D., et al. (2020). A united front against marine invaders: developing a cost-effective marine biosecurity surveillance partnership between government and industry. J. Appl. Ecol. 57, 77-84. doi: 10.1111/1365-2664. 13557

McDonald, J., Wilkens, S., Stanley, J., and Jeffs, A. (2014). Vessel generator noise as a settlement cue for marine biofouling species. Biofouling 30, 741-749. doi: 10.1080/08927014.2014.919630

Mineur, F., Cook, E., Minchin, D., Bohn, K., Macleod, A., and Maggs, C. (2012). Changing coasts: marine aliens and artificial structures. Oceanogr. Mar. Biol. Ann. Rev. 50, 189-234. doi: 10.1201/B12157-6

Ministry for Primary Industries (2014). Craft Risk Management Standard: Biofouling on Vessels Arriving to New Zealand. Wellington: Ministry for Primary Industries.

Ministry for Primary Industries and Aquaculture New Zealand (2016). Aquaculture Biosecurity Handbook: Assisting New Zealand's Commercial and Non-Commercial Aquaculture to Minimise Aquaculture Biosecurity Risk. Wellington: Ministry for Primary Industries and Aquaculture New Zealand.

Mitchem, E. L., Fajans, J. S., and Baker, S. M. (2007). Contrasting response of two native crustaceans to non-indigenous prey, the green mussel, Perna viridis. Fla. Sci. 70, 180-188.

Molnar, J. L., Gamboa, R. L., Revenga, C., and Spalding, M. D. (2008). Assessing the global threat of invasive species to marine biodiversity. Front. Ecol. Environ. 6, 485-492. doi: 10.1890/070064

Momber, A. W., Plagemann, P., and Stenzel, V. (2015). Performance and integrity of protective coating systems for offshore wind power structures after three years under offshore site conditions. Renew. Energy 74, 606-617. doi: 10.1016/j. renene.2014.08.047

Moodie, L. W., Trepos, R., Cervin, G., Larsen, L., Larsen, D. S., Pavia, H., et al. (2017). Probing the structure-activity relationship of the natural antifouling agent polygodial against both micro-and macrofoulers by semisynthetic modification. J. Nat. Prod. 80, 515-525. doi: 10.1021/acs.jnatprod.6b01056

Morrisey, D., Inglis, G., Tait, L., Woods, C., Lewis, J., and Georgiades, E. (2015). Procedures for Evaluating in-Water Systems to Remove or Treat Vessel Biofouling. Available online at: http://www.mpi.govt.nz/document-vault/10811 (accessed March 12, 2021).

Myan, F. W. Y., Walker, J., and Paramor, O. (2013). The interaction of marine fouling organisms with topography of varied scale and geometry: a review. Biointerphases 8:30. doi: 10.1186/1559-4106-8-30

Neitzel, D. A., Johnson, K. I., Page, T. L., Young, J. S., and Daling, P. M. (1984). Correlation of Bivalve Biological Characteristics and Service Water System Design. Report No. NUREG/CR 4070. Washington: United States Nuclear Regulatory Commission.

New Zealand Environmental Protection Authority (2013). Evaluation and Review Report for The Reassessment of Antifouling Paints (APP201051). Wellington: New Zealand Environmental Protection Authority.

Newton, M. (2019). Stakeholder Views on Reducing the Risk of Marine Pest Spread by Recreational Boat Operators. Cawthron Institute Report No. 3397. Nelson: Cawthron Institute.

Ohrem, S. J., Kelasidi, E., and Bloecher, N. (2020). “Analysis of a novel autonomous underwater robot for biofouling prevention and inspection in fish farms," in Proceedings of the 2020 28th Mediterranean Conference on Control and Automation (MED), Wellington, 1002-1008.

Omran, B. A., and Abdel-Salam, M. O. (2020). "The catastrophic battle of biofouling in oil and gas facilities: impacts, history, involved microorganisms, biocides and polymer coatings to combat biofouling," in A New Era for Microbial Corrosion Mitigation Using Nanotechnology, eds M. O. Abdel-Salam and B. A. Omran (Cham: Springer), 47-99.

Pagenkopp-Lohan, K. M., Ruiz, G. M., and Torchin, M. E. (2020). "Invasions can drive marine disease dynamics," in Marine Disease Ecology, eds D. C. Behringer, K. D. Lafferty, and B. D. Silliman (Oxford: Oxford University Press), 115-138.

Piazza, V., Gambardella, C., Garaventa, F., Massanisso, P., Chiavarini, S., and Faimali, M. (2018). A new approach to testing potential leaching toxicity of fouling release coatings (FRCs). Mar. Environ Res 141, 305-312. doi: 10.1016/j. marenvres.2018.09.024
Pinori, E. (2013). Low Biocide Emission Antifouling Based on a Novel Route of Barnacle Intoxication. Available online at: http://leaf-antifouling.eu/ (accessed July 26, 2021).

Piola, R. F., and Hopkins, G. A. (2012). Thermal treatment as a method to control transfers of invasive biofouling species via vessel sea chests. Mar. Pollut. Bull. 64, 1620-1630. doi: 10.1016/j.marpolbul.2012.05.028

Polman, H., Verhaart, F., and Bruijs, M. (2013). Impact of biofouling in intake pipes on the hydraulics and efficiency of pumping capacity. Desalin. Water Treat. 51, 997-1003. doi: 10.1080/19443994.2012.707371

Price, S. J., and Figueira, R. B. (2017). Corrosion protection systems and fatigue corrosion in offshore wind structures: current status and future perspectives. Coatings 7:25. doi: 10.3390/coatings7020025

Qian, P. Y., Chen, L., and Xu, Y. (2013). Mini-review: molecular mechanisms of antifouling compounds. Biofouling 29, 381-400. doi: 10.1080/08927014.2013. 776546

Qian, P. Y., Li, Z., Xu, Y., Li, Y., and Fusetani, N. (2015). Mini-review: marine natural products and their synthetic analogs as antifouling compounds: 20092014. Biofouling 31, 101-122. doi: 10.1080/08927014.2014.997226

Rahimi, A., Stafslien, S. J., Vanderwal, L., Bahr, J., Safaripour, M., Finlay, J. A., et al. (2021). Critical amphiphilic concentration: effect of the extent of amphiphilicity on marine fouling-release performance. Langmuir 31, 2728-2739. doi: 10.1021/ acs.langmuir.0c03446

Rajagopal, S., and Van der Velde, G. (2012). "Invasive species: implications for industrial cooling water systems," in Operational and Environmental Consequences of Large Industrial Cooling Water Systems, eds S. Rajagopal, H. A. Jenner, and V. P. Venugopalan (Berlin: Springer), 127-162.

Ravel, B. (2020). Antifouling coatings: a need for innovation. J. Prot. Coat. Linings 37, 30-36.

Rémouit, F., Chatzigiannakou, M.-A., Bender, A., Temiz, I., Sundberg, F., and Engström, J. (2018). Deployment and maintenance of wave energy converters at the Lysekil Research Site: a comparative study on the use of divers and remotely-operated vehicles. J. Mar. Sci. Eng. 6:39. doi: 10.3390/jmse6020039

Richards, C., Briciu-Burghina, C., Jacobs, M. R., Barrett, A., and Regan, F. (2019). Assessment of antifouling potential of novel transparent sol gel coatings for application in the marine environment. Molecules 24:2983. doi: 10.3390/ molecules 24162983

Richir, J., Bray, S., McAleese, T., and Watson, G. J. (2021). Three decades of trace element sediment contamination: the mining of governmental databases and the need to address hidden sources for clean and healthy seas. Environ. Int. 149:106362. doi: 10.1016/j.envint.2020.106362

Roche, R. C., Monnington, J. M., Newstead, R. G., Sambrook, K., Griffith, K., Holt, R. H. F., et al. (2015). Recreational vessels as a vector for marine non-natives: developing biosecurity measures and managing risk through an inwater encapsulation system. Hydrobiologia 750, 187-199. doi: 10.1007/s10750014-2131-y

Ross, K. A., Thorpe, J. P., and Brand, A. R. (2004). Biological control of fouling in suspended scallop cultivation. Aquaculture 229, 99-116. doi: 10.1016/S00448486(03)00328-4

Sandberg, M. G., and Olafsen, T. (2006). Overview of Laws and Regulations Regarding Antifouling Methods in Fish Farming. SINTEF Fisheries and Aquaculture Report SFH80A066001. Trondheim: SINTEF Fisheries and Aquaculture.

Satpathy, K. K. (1999). Effects of bio-fouling on the cooling water quality of a nuclear power plant. Bull. Electrochem. 15, 143-147.

Satpathy, K. K., Mohanty, A. K., Sahu, G., Biswas, S., Prasad, M. V. R., and Slvanayagam, M. (2010). "Biofouling and its control in seawater cooled power plant cooling water system- a review," in Nuclear Power, ed. P. Tsvetkov (Rijeka: Sciyo), 191-242.

Satpathy, K. K., and Rajmohan, R. (2001). "Effects of fouling organisms on the water quality of a nuclear power plant cooling system," in Proceedings of the 10th International Congress on Marine Corrosion and Fouling, (Parkville: University of Melbourne).

Scardino, A. J., de Nys, R., Ison, O., O’Connor, W., and Steinberg, P. (2003). Microtopography and antifouling properties of the shell surface of the bivalve molluscs Mytilus galloprovincialis and Pinctada imbricata. Biofouling 19, $221-$ 230. doi: 10.1080/0892701021000057882 
Scardino, A. J., Fletcher, L. E., and Lewis, J. A. (2009). Fouling control using air bubble curtains: protection for stationary vessels. J. Mar. Eng. Technol. A13, 3-10. doi: 10.1080/20464177.2009.11020214

Schultz, M. P., Bendick, J. A., Holm, E. R., and Hertel, W. M. (2011). Economic impact of biofouling on a naval surface ship. Biofouling 27, 87-98. doi: 10.1080/ 08927014.2010.542809

Schumacher, J., Aldred, N., Callow, M., Finlay, J., Callow, J., Clare, A., et al. (2007). Species-specific engineered antifouling topographies: correlations between the settlement of algal zoospores and barnacle cyprids. Biofouling 23, 307-317. doi: 10.1080/08927010701393276

Scott, J. K., McKirdy, S. J., van der Merwe, J., Green, R., Burbidge, A. A., Pickles, G., et al. (2017). Zero-tolerance biosecurity protects high-conservationvalue island nature reserve. Sci. Rep. 7:772. doi: 10.1038/s41598-01700450-y

Seaward, K., Acosta, H., Inglis, G. J., Wood, B., Riding, T., Wilkens, S., et al. (2015). The marine biosecurity porthole - a web-based information system on nonindigenous marine species in New Zealand. Manag. Biol. Invasion 6, 177-184. doi: 10.3391/mbi.2015.6.2.08

Selim, M. S., Shenashen, M. A., El-Safty, S. A., Higazy, S. A., Selim, M. M., Isago, H., et al. (2017). Recent progress in marine foul-release polymeric nanocomposite coatings. Prog. Mater. Sci. 87, 1-32. doi: 10.1016/j.pmatsci.2017. 02.001

Sievers, M., Dempster, T., Keough, M., and Fitridge, I. (2019). Methods to prevent and treat biofouling in shellfish aquaculture. Aquaculture 505, 263-270. doi: 10.1016/j.aquaculture.2019.02.071

Sim-Smith, C., Faire, S., and Lees, A. (2016). Managing Biosecurity for Business Benefit. Aquaculture Biosecurity Practices Research. Technical Paper No. 2016/14. Wellington: Ministry for Primary Industries.

Sørensen, P. A., Kiil, S., Dam-Johansen, K., and Weinell, C. E. (2009). Anticorrosive coatings: a review. J. Coat. Technol. Res. 6, 135-176. doi: 10.1007/s11998-0089144-2

Stankiewicz, A., Szczygieł, I., and Szczygieł, B. (2013). Self-healing coatings in anticorrosion applications. J. Mater. Sci. 48, 8041-8051. doi: 10.1007/s10853-0137616-y

Sullivan, T., and O'Callaghan, I. (2020). Recent developments in biomimetic antifouling materials: a review. Biomimetics 5:58. doi: 10.3390/biomimetics5040058

Sundberg, A. (2015). Molluscan Explosion: the Dutch Shipworm Epidemic of the 1730s. Environment \& Society Portal, Arcadia, no. 14. München: Rachel Carson Center for Environment and Society.

Switzer, S. E., Therriault, T. W., Dunham, A., and Pearce, C. M. (2011). Assessing potential control options for the invasive tunicate Didemnum vexillum in shellfish aquaculture. Aquaculture 318, 145-153. doi: 10.1016/j.aquaculture. 2011.04.044

Szeto, W., Leung, M. K., and Leung, D. Y. (2020). Recent developments of titanium dioxide materials for aquatic antifouling application. J. Mar. Sci. Technol. 26, 301-321. doi: 10.1007/s00773-020-00720-x

Tamburri, M. N., Davidson, I. C., First, M. R., Scianni, C., Newcomer, K., Inglis, G. J., et al. (2020). In-water cleaning and capture to remove ship biofouling: an initial evaluation of efficacy and environmental safety. Front. Mar. Sci. 7:437. doi: 10.3389/fmars.2020.00437

Todd, P. A., Heery, E. C., Loke, L. H., Thurstan, R. H., Kotze, D. J., and Swan, C. (2019). Towards an urban marine ecology: characterizing the drivers, patterns and processes of marine ecosystems in coastal cities. Oikos 128, 1215-1242. doi: 10.1111/oik.05946

Townsin, R. L. (2003). The ship hull fouling penalty. Biofouling 19, 9-15. doi: 10.1080/0892701031000088535

Trepos, R., Cervin, G., Pile, C., Pavia, H., Hellio, C., and Svenson, J. (2015). Evaluation of cationic micropeptides derived from the innate immune system as inhibitors of marine biofouling. Biofouling 31, 393-403. doi: 10.1080/08927014. 2015.1048238

Tsinker, G. P. (2004). Port Engineering: Planning, Construction, Maintenance and Security. Hoboken, NJ: Wiley.

Venkatesan, R., and Murthy, P. S. (2009). "Macrofouling control in power plants," in Marine and Industrial Biofouling, eds H. C. Flemming, P. S. Murthy, R. Venkatesan, and K. Cooksey (Berlin: Springer), $265-291$.
Versowsky, P. E. (2005). Rationalization and optimization of coatings maintenance programs for corrosion management on offshore platforms. NIST Publ. 1035, $170-177$.

Vinagre, P. A., Simas, T., Cruz, E., Pinori, E., and Svenson, J. (2020). Marine biofouling: a European database for the marine renewable energy sector. J. Mar. Sci. Eng. 8:495. doi: 10.3390/jmse807 0495

Vucko, M. J., Poole, A. J., Sexton, B. A., Glenn, F. L., Carl, C., Whalan, S., et al. (2013). Combining a photocatalyst with microtopography to develop effective antifouling materials. Biofouling 29, 751-762. doi: 10.1080/08927014. 2013.803193

Wahl, M. (1989). Marine epibiosis. I. Fouling and antifouling: some basic aspects. Mar. Ecol. Prog. Ser. 58, 175-189. doi: 10.3354/meps 058175

Wanka, R., Koc, J., Clarke, J., Hunsucker, K. Z., Swain, G. W., Aldred, N., et al. (2020). Sol gel-based hybrid materials as antifouling and fouling-release coatings for marine applications. ACS Appl. Mater. Interfaces 12, 53286-53296. doi: 10.1021/acsami.0c15288

Wanless, R. M., Scott, S., Sauer, W. H., Andrew, T. G., Glass, J. P., Godfrey, B., et al. (2010). Semi-submersible rigs: a vector transporting entire marine communities around the world. Biol. Invasions 12, 2573-2583. doi: 10.1007/s10530-0099666-2

Ware, C. S., Smith-Palmer, T., Peppou-Chapman, S., Scarratt, L. R., Humphries, E. M., Balzer, D., et al. (2018). Marine antifouling behavior of lubricant-infused nanowrinkled polymeric surfaces. ACS Appl. Mater. Interfaces 10, 4173-4182. doi: $10.1021 /$ acsami.7b14736

Wayman, C., and Niemann, H. (2021). The fate of plastic in the ocean environment - a minireview. Environ. Sci. Process. Impacts 23, 198-212. doi: 10.1039/D0EM00446D

Wei, M. Y., Wang, C. F., Wang, K. L., Qian, P. Y., Wang, C. Y., and Shao, C. L. (2017). Preparation, structure, and potent antifouling activity of sclerotioramine derivatives. Mar. Biotechnol. 19, 372-378. doi: 10.1007/s10126017-9760-x

Whittington, R. J., Paul-Pont, I., Evans, O., Hick, P., and Dhand, N. K. (2018). Counting the dead to determine the source and transmission of the marine herpesvirus OsHV-1 in Crassostrea gigas. Vet. Res. 49:34. doi: 10.1186/s13567018-0529-7

Wilkens, S., Stanley, J., and Jeffs, A. (2012). Induction of settlement in mussel (Perna canaliculus) larvae by vessel noise. Biofouling 28, 65-72. doi: 10.1080/ 08927014.2011.651717

Woods, C., Seaward, K., Pryor Rodgers, L., Buckthought, D., Carter, M., Lyon, W., et al. (2019). Marine High Risk Site Surveillance. Annual Synopsis Report for all High Risk Sites 2018-2019. Biosecurity New Zealand Technical Paper No. 2019/31. Wellington: Ministry for Primary Industries.

Woods Hole Oceanographic Institute [WHOI] (1952). Marine Fouling and its Prevention. Contribution No. 580 from Woods Hole Oceanographic Institute. Annapolis, MD: United States Naval Institute.

Wotton, D., O’Brien, C., Stuart, M. D., and Fergus, D. (2004). Eradication success down under: heat treatment of a sunken trawler to kill the invasive seaweed Undaria pinnatifida. Mar. Pollut. Bull. 49, 844-849. doi: 10.1016/j.marpolbul. 2004.05.001

Xie, Q., Pan, J., Ma, C., and Zhang, G. (2019). Dynamic surface antifouling: mechanism and systems. Soft. Matter. 15, 1087-1107. doi: 10.1039/C8SM01853G

Yan, H., Wu, Q., Yu, C., Zhao, T., and Liu, M. (2020). Recent progress of biomimetic antifouling surfaces in marine. Adv. Mater. Interfaces 7:2000966. doi: 10.1002/admi.202000966

Yang, S.-H., Ringsberg, J. W., Johnson, E., and Hu, Z. (2017). Biofouling on mooring lines and power cables used in wave energy converter systemsanalysis of fatigue life and energy performance. Appl. Ocean Res. 65, 166-177. doi: 10.1016/j.apor.2017.04.002

Yang, W., Zhang, R., Wu, Y., Pei, X., Liu, Y., and Zhou, F. (2018). Enhancement of graft density and chain length of hydrophilic polymer brush for effective marine antifouling. J. Appl. Polym. Sci. 135:46232. doi: 10.1002/app. 46232

Ye, L., Wu, L., Wang, Z., Jiang, J., and Wang, J. (2019). Control of biofouling on pearl oysters Pinctada imbricata using wax and 
Chinese herbs. Biofouling 35, 649-657. doi: 10.1080/08927014.2019. 1641201

Yebra, D. M., Kiil, S., and Dam-Johansen, K. (2004). Antifouling technologypast, present and future steps towards efficient and environmentally friendly antifouling coatings. Prog. Org. Coat. 50, 75-104. doi: 10.1016/j.porgcoat.2003. 06.001

Yeo, D. C., Ahyong, S. T., Lodge, D. M., Ng, P. K., Naruse, T., and Lane, D. J. (2010). Semisubmersible oil platforms: understudied and potentially major vectors of biofouling-mediated invasions. Biofouling 26, 179-186. doi: 10.1080/ 08927010903402438

Zhang, F., Ju, P., Pan, M., Zhang, D., Huang, Y., Li, G., et al. (2018). Self-healing mechanisms in smart protective coatings: a review. Corros. Sci. 144, 74-88. doi: 10.1016/j.corsci.2018.08.005

Zhang, X., Zhang, J., Yu, J., Zhang, Y., Yu, F., Jia, L., et al. (2019). Enhancement in the photocatalytic antifouling efficiency over cherimoya-like InVO4/BiVO4 with a new vanadium source. J. Colloid Interface Sci. 533, 358-368. doi: 10.1016/ j.jcis.2018.06.090
Conflict of Interest: The authors declare that the research was conducted in the absence of any commercial or financial relationships that could be construed as a potential conflict of interest.

Publisher's Note: All claims expressed in this article are solely those of the authors and do not necessarily represent those of their affiliated organizations, or those of the publisher, the editors and the reviewers. Any product that may be evaluated in this article, or claim that may be made by its manufacturer, is not guaranteed or endorsed by the publisher.

Copyright $\odot 2021$ Hopkins, Davidson, Georgiades, Floerl, Morrisey and Cahill. This is an open-access article distributed under the terms of the Creative Commons Attribution License (CC BY). The use, distribution or reproduction in other forums is permitted, provided the original author $(s)$ and the copyright owner(s) are credited and that the original publication in this journal is cited, in accordance with accepted academic practice. No use, distribution or reproduction is permitted which does not comply with these terms. 